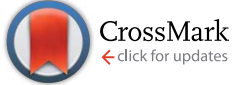

Cite this: RSC Adv., 2016, 6, 32258

\title{
Highly purified CNTs: an exceedingly efficient catalyst support for PEM fuel cell $\uparrow$
}

\author{
Chanchal Gupta, ${ }^{\text {ab }}$ Priyanka H. Maheshwari, ${ }^{\text {ab }}{ }^{\text {Divya Sachdev, }}{ }^{c}$ A. K. Sahu ${ }^{d}$ \\ and S. R. Dhakate ${ }^{a b}$
}

\begin{abstract}
High performance in PEM fuel cells has been achieved using purified CNTs as catalyst support. Pt/CNT nanocomposites were synthesized by reducing Pt salt on CNTs in the presence of ethylene glycol as solvent and in inert atmosphere. The reactions were carried out using both pristine and purified MWCNTs under different $\mathrm{pH}$ and atmospheric conditions. The detailed physical and electrochemical characterization revealed that a highly active catalytic surface could be achieved on reducing Pt on defect-free, purified MWCNTs. A further elaborated mechanism is discussed, which illustrates that reduced $\mathrm{Pt}$ nanoparticles form a chelate in the presence of nitrogen at neutral $\mathrm{pH}$. This results in increased stability and enhanced catalytic activity. The $I-V$ performance of a unit PEM fuel cell using the synthesized catalyst (with purified CNTs as catalyst support) showed a peak power density of $818 \mathrm{~mW}$ $\mathrm{cm}^{-2}$. The performance repeated in triplicate was found to be consistent and exceptionally high ( $\left.>80 \%\right)$ in comparison with $448 \mathrm{~mW} \mathrm{~cm}^{-2}$, the value obtained while employing pristine CNTs as support and tested under similar conditions. Moreover, a novel experimental support was given to confirm the number of electrons involved in the oxygen reduction reaction (ORR) on these highly purified CNT supported catalysts
\end{abstract}

Received 30th December 2015

Accepted 5th March 2016

DOI: $10.1039 / \mathrm{c} 5 \mathrm{ra28029j}$

www.rsc.org/advances supersede the conventional energy sources, there is a need to increase the durability and reduce the cost of the PEMFC. An ideal approach would be to reduce the required amount of Pt (catalyst) while sustaining high FC performance. This is possible by increasing the surface area of the Pt particles via a reduction in its size; however, decreasing size can result in other problems such as thermal stability. Therefore, new routes for development of highly active and stable catalyst substrate/ support have become the focal point.

In view of the above requirements, the ideal catalyst support must have some distinct characteristics: it should be electrochemically active, must remain well dispersed to prevent agglomeration of the electro-catalyst, and, at the same time, it should have structural uniformity to provide identical reaction sites. ${ }^{10}$ Also, a support with high surface area should be conducting, resistant to corrosion, and hydrophobic, to avoid any mass transport problem while enhancing the activity of catalyst. Particularly varied examples in the literature have indicated that tailored morphologies and surface modifications of the support material, especially carbon-based materials such as carbon black, ${ }^{11-21}$ mesocarbon micro beads (MCMB), ${ }^{2-25}$ carbon fibers, vapor grown carbon fibers (VGCF), ${ }^{26-28}$ carbon nanotubes (CNTs), ${ }^{21,27,29-38}$ graphene ${ }^{39-43}$ and others, ${ }^{44-46}$ greatly influences the catalytic properties. A brief account of these is given in Table 1 along with the fuel cell power density achieved for a given catalyst loading (on the cathode side).

\footnotetext{
${ }^{a}$ Physics and Engineering of Carbon, CSIR - National Physical Laboratory, New Delhi, India. E-mail: hedap@mail.nplindia.ernet.in; Fax: +91 11 45609310; Tel: +91 11 45608508

${ }^{b}$ Academy of Scientific and Innovative Research (AcSIR), CSIR-NPL Campus, New Delhi, India

${ }^{c}$ National Institute of Food Technology Entrepreneurship and Management, Sonepat, India

${ }^{d}$ CSIR-Central Electrochemical Research Institute, Chennai, India

$\dagger$ Electronic supplementary information (ESI) available. See DOI 10.1039/c5ra28029j
} 
Table 1 Different carbon-based catalyst materials with catalyst loading on cathode side and their respective fuel cell performance

\begin{tabular}{|c|c|c|c|c|}
\hline & Description of catalyst $\{$ method of preparation $\}$ & $\begin{array}{l}\text { Catalyst loading } \\
\text { cathode }\end{array}$ & $\begin{array}{l}\text { Fuel cell peak power density; current } \\
\text { density }\end{array}$ & Ref. \\
\hline 1 & Commercial Pt black & $0.5 \mathrm{mg} \mathrm{cm}^{-2} \mathrm{Pt}$ & $580 \mathrm{~mW} \mathrm{~cm}^{-2}$ at $\sim 1400 \mathrm{~mA} \mathrm{~cm}{ }^{-2}$ & 20 \\
\hline 2 & $\begin{array}{l}\text { Pure } \mathrm{Pt}\left(\mathrm{NaBH}_{4} \text { reduction of } \mathrm{H}_{2} \mathrm{PtCl}_{6} \text { in neutral }\right. \\
\text { medium })\end{array}$ & $0.2 \mathrm{mg} \mathrm{cm}^{-2}$ & $100 \mathrm{~mW} \mathrm{~cm}{ }^{-2} ; 200 \mathrm{~mA} \mathrm{~cm}{ }^{-2}$ & 37 \\
\hline 3 & Pt/C (Vulcan XC-72), 10\% Pt (EG method) & $1.0 \mathrm{mg} \mathrm{cm}^{-2}$ & $73 \mathrm{~mW} \mathrm{~cm}{ }^{-2} ; 260 \mathrm{~mA} \mathrm{~cm}^{-2}$ & 13 \\
\hline 4 & $\begin{array}{l}\mathrm{Pt} / \mathrm{C} \text { (Vulcan XC-72), 20\% Pt (microwave assisted polyol } \\
\text { method) }\end{array}$ & $2-3 \mathrm{mg} \mathrm{cm}^{-2}$ & $\sim 0.7 \mathrm{~V}$ @ $\sim 0.69 \mathrm{~mA} \mathrm{~cm}^{-2}$ & 14 \\
\hline 5 & $\begin{array}{l}60 \% \mathrm{Pt} / \mathrm{C} \\
40 \mathrm{wt} \% \mathrm{Pt} / \mathrm{C} \\
20 \mathrm{wt} \% \mathrm{Pt} / \mathrm{C} \text { (urea assisted EG method) }\end{array}$ & $0.2 \mathrm{mg} \mathrm{cm}^{-2}$ & $\begin{array}{l}\sim 400 \mathrm{~mW} \mathrm{~cm}^{-2} ; 850 \mathrm{~mA} \mathrm{~cm}^{-2} \\
370 \mathrm{~mW} \mathrm{~cm}^{-2} ; 800 \mathrm{~mA} \mathrm{~cm}^{-2} \\
340 \mathrm{~mW} \mathrm{~cm}^{-2} ; 800 \mathrm{~mA} \mathrm{~cm}{ }^{-2}\end{array}$ & 15 \\
\hline 6 & $60 \% \mathrm{Pt} / \mathrm{C}\left(\mathrm{NaBH}_{4}\right.$ reduction $)$ & $0.2 \mathrm{mg} \mathrm{cm}^{-2}$ & $\sim 225 \mathrm{~mW} \mathrm{~cm}^{-2} ; \sim 600 \mathrm{~mA} \mathrm{~cm}^{-2}$ & 15 \\
\hline 7 & $60 \mathrm{wt} \% \mathrm{Pt} / \mathrm{C}$ (microwave assisted EG method) & $0.2 \mathrm{mg} \mathrm{cm}^{-2}$ & $\sim 225 \mathrm{~mW} \mathrm{~cm}^{-2} ; \sim 600 \mathrm{~mA} \mathrm{~cm}{ }^{-2}$ & 15 \\
\hline 8 & $\mathrm{Pt} / \mathrm{C}$ (Vulcan XC-72) (microwave assisted EG reduction) & $0.8 \mathrm{mg} \mathrm{cm}^{-2}$ & $\sim 27 \mathrm{~mW} \mathrm{~cm}^{-2}$ at $\sim 120 \mathrm{~mA} \mathrm{~cm}^{-2}$ & 16 \\
\hline 9 & $\begin{array}{l}\text { Pt/C-PNIPAM (commercial catalyst selectively } \\
\text { functionalized with thermally responsive } \operatorname{poly}\left(N^{-}\right. \\
\text {isopropylacrylamide)) }\end{array}$ & $0.2 \mathrm{mg} \mathrm{cm}^{-2}$ & $810 \mathrm{~mW} \mathrm{~cm}^{-2}$ at $\sim 1540 \mathrm{~mA} \mathrm{~cm}^{-2}$ & 17 \\
\hline 10 & $\begin{array}{l}46 \% \mathrm{Pt} / \mathrm{C} \text { (Ketjenblack, BET surface area } 800 \mathrm{~m}^{2} \mathrm{~g}^{-1} \text { ) } \\
(\text { EG reduction in the presence of } \mathrm{NaOH})\end{array}$ & $0.4 \mathrm{mg} \mathrm{cm}^{-2}$ & $0.7 \mathrm{~V}$ @ $\sim 2200 \mathrm{~mA} \mathrm{~cm}{ }^{-2}$ & 18 \\
\hline 11 & $\begin{array}{l}20 \% \mathrm{Pt} / \text { carbon nanocoils (CNC by graphitization of } \\
\text { resorcinol formaldehyde gel) } \\
\text { Catalyst by borohydride reduction (ETEK } 20 \mathrm{wt} \% \mathrm{Pt} / \mathrm{C} \\
0.4 \mathrm{mg} \mathrm{cm}^{-2} \text { ) }\end{array}$ & $\begin{array}{l}\text { Prepared catalyst at } \\
\text { anode } 0.4 \mathrm{mg} \mathrm{cm}^{-2}\end{array}$ & $320 \mathrm{~mW} \mathrm{~cm}^{-2}$ at $\sim 705 \mathrm{~mA} \mathrm{~cm}^{-2}$ & 19 \\
\hline 12 & Commercial Pt/C & $0.5 \mathrm{mg} \mathrm{cm}^{-2} \mathrm{Pt}$ & $810 \mathrm{~mW} \mathrm{~cm} \mathrm{~cm}^{-2} @ \sim 1900 \mathrm{~mA} \mathrm{~cm}{ }^{-2}$ & 20 \\
\hline 13 & $\mathrm{Pt} / \mathrm{C} 19.5 \% \mathrm{Pt}$ (microwave assisted polyol method) & $0.4 \mathrm{mg} \mathrm{cm}^{-2}$ & $\sim 240 \mathrm{~mW} \mathrm{~cm}^{-2}$ at $500 \mathrm{~mA} \mathrm{~cm}^{-2}$ & 21 \\
\hline 14 & $\begin{array}{l}\text { Pt/MCMB (acid functionalized mesocarbon micro } \\
\text { beads) (EG reduction method) }\end{array}$ & $1.6 \mathrm{mg} \mathrm{cm}^{-2}$ & Did not show FC activity & 22 \\
\hline 15 & $\begin{array}{l}\mathrm{Pt} / \text { HCMSC (hollow core-mesoporous shell carbon), } \\
40 \% \text { Pt loading by microwave assisted polyol method }\end{array}$ & $0.2 \mathrm{mg} \mathrm{cm}^{-2}$ & $480 \mathrm{~mW} \mathrm{~cm}{ }^{-2} ; \sim 1120 \mathrm{~cm}^{2}$ & 44 \\
\hline 16 & $\begin{array}{l}\text { Pt/ordered hierarchical nanostructure carbon } \\
\text { (produced by inverse replication of silica template), } \\
40 \% \text { Pt loading by microwave assisted polyol method }\end{array}$ & $0.2 \mathrm{mg} \mathrm{cm}^{-2}$ & $\sim 460 \mathrm{~mW} \mathrm{~cm}^{-2}$ at $\sim 1000 \mathrm{~mA} \mathrm{~cm}{ }^{-2}$ & 45 \\
\hline 17 & $20 \% \mathrm{Pt} / \mathrm{VGCF}$ (colloidal polyol method) & $0.529 \mathrm{mg} \mathrm{cm}^{-2}$ & $<200 \mathrm{~mW} \mathrm{~cm}^{-2} ; 500 \mathrm{~mA} \mathrm{~cm} \mathrm{c}^{-2}$ & 27 \\
\hline 18 & $\begin{array}{l}\mathrm{Pt} / \mathrm{MWCNT}, 20 \% \mathrm{Pt} \text { (EG reduction method, refluxing in } \\
\text { air) }\end{array}$ & $0.529 \mathrm{mg} \mathrm{cm}^{-2}$ & $170 \mathrm{~mW} \mathrm{~cm} \mathrm{~cm}^{-2} ; 380 \mathrm{~mA} \mathrm{~cm}{ }^{-2}$ & 27 \\
\hline 19 & $\begin{array}{l}\text { Pt/MWCNT (acid functionalized), electroless plating } \\
\text { facilitated by pre-sensitization }\end{array}$ & $2-3 \mathrm{mg} \mathrm{cm}^{-2}$ & $350 \mathrm{~mW} \mathrm{~cm}{ }^{-2} ; 500 \mathrm{~mA} \mathrm{~cm}^{-2}$ & 29 \\
\hline 20 & $\begin{array}{l}\text { Pt/MWCNTs (acid functionalized) (EG reduction } \\
\text { method, refluxing in air) }\end{array}$ & $1.0 \mathrm{mg} \mathrm{cm}^{-2}$ & $103 \mathrm{~mW} \mathrm{~cm}^{-2}$ & 30 \\
\hline 21 & $\begin{array}{l}\text { Oriented Pt/MWCNT, } 30 \% \mathrm{Pt} \text {, prepared by EG } \\
\text { reduction method, refluxing in air }\end{array}$ & $0.2 \mathrm{mg} \mathrm{cm}^{-2}$ & $0.6 \mathrm{~V}$ at $\sim 820 \mathrm{~mA} \mathrm{~cm}^{-2}$ & 35 \\
\hline 22 & $\mathrm{Pt} / \mathrm{MWCNT}, 10 \% \mathrm{Pt}$ (EG method refluxing in $\mathrm{Ar}$ ) & $1.0 \mathrm{mg} \mathrm{cm}^{-2}$ & $\sim 105 \mathrm{~mW} \mathrm{~cm}^{-2} ; 365 \mathrm{~mA} \mathrm{~cm}{ }^{-2}$ & 13 \\
\hline 23 & $\mathrm{Pt} / \mathrm{MWCNT}, 10 \% \mathrm{Pt}$ (HCHO reduction) & $1.0 \mathrm{mg} \mathrm{cm}^{-2}$ & $85 \mathrm{~mW} \mathrm{~cm}{ }^{-2} ; 300 \mathrm{~mA} \mathrm{~cm}{ }^{-2}$ & 13 \\
\hline 24 & $\begin{array}{l}\mathrm{Pt} / \mathrm{MWCNT}, 20 \% \mathrm{Pt} \text { (microwave assisted polyol } \\
\text { method) }\end{array}$ & $2-3 \mathrm{mg} \mathrm{cm}^{-2}$ & $\sim 0.7 \mathrm{~V}$ @ $\sim 0.7 \mathrm{~mA} \mathrm{~cm}^{-2}$ & 14 \\
\hline 25 & Pt/MWCNT, 20\% Pt (colloidal polyol method) & $0.529 \mathrm{mg} \mathrm{cm}^{-2}$ & $<150 \mathrm{~mW} \mathrm{~cm}^{-2} ; 350 \mathrm{~mA} \mathrm{~cm}{ }^{-2}$ & 27 \\
\hline 26 & $\begin{array}{l}\text { Pt-MWCNT (CNTs deposited on carbon paper by CCVD } \\
\text { technique followed by Pt reduction by microwave } \\
\text { assisted polyol method), } 16 \text { wt } \% \text { Pt loading }\end{array}$ & - & $535 \mathrm{~mW} \mathrm{~cm}^{-2}$ at $400 \mathrm{~mA} \mathrm{~cm}-2$ & 31 \\
\hline 27 & Pt/MWCNTs (EG method $\{5 \%$ water $\}$ refluxing in $\mathrm{Ar}$ ) & $1.0 \mathrm{mg} \mathrm{cm}^{-2}$ & $0.309 \mathrm{~V} @ 300 \mathrm{~mA} \mathrm{~cm}{ }^{-2}$ & 32 \\
\hline 28 & $\begin{array}{l}\text { Pt/SWCNTs, } 17 \% \text { Pt (microwave assisted polyol } \\
\text { method) }\end{array}$ & $0.4 \mathrm{mg} \mathrm{cm}^{-2}$ & $\sim 330 \mathrm{~mW} \mathrm{~cm}^{-2}$ at $630 \mathrm{~mA} \mathrm{~cm}^{-2}$ & 21 \\
\hline 29 & $\begin{array}{l}\mathrm{Pt} / \mathrm{SWCNTs}, 20 \% \mathrm{Pt} \text { (acid functionalized CNTs, } \\
\text { microwave assisted polyol method) }\end{array}$ & $0.4 \mathrm{mg} \mathrm{cm}^{-2}$ & $\sim 360 \mathrm{~mW} \mathrm{~cm}^{-2}$ at $710 \mathrm{~mA} \mathrm{~cm}^{-2}$ & 21 \\
\hline 30 & $\begin{array}{l}\mathrm{Pt} / \mathrm{MWCNTs} \text { (acid functionalized, } \mathrm{NaBH}_{4} \text { reduction } \\
\text { method) }\end{array}$ & $0.5 \mathrm{mg} \mathrm{cm}^{-2}$ & $0.72 \mathrm{~V}$ at $\sim 400 \mathrm{~mA} \mathrm{~cm}^{-2}$ & 33 \\
\hline 31 & $\begin{array}{l}\text { Pt/MWCNTs (acid functionalization of CNTs, EG } \\
\text { reduction method, refluxing in air) }\end{array}$ & $0.2 \mathrm{mg} \mathrm{cm}^{-2}$ & $532 \mathrm{~mW} \mathrm{~cm}^{-2}$ & 34 \\
\hline 32 & $\begin{array}{l}\text { Pt/MWCNTs (acid functionalized) (EG reduction } \\
\text { method) }\end{array}$ & $1.6 \mathrm{mg} \mathrm{cm}^{-2}$ & $\sim 75 \mathrm{~mW} \mathrm{~cm}^{-2} ; 190 \mathrm{~mA} \mathrm{~cm}{ }^{-2}$ & 22 \\
\hline 33 & Pt/graphene oxide (reduction by L-ascorbic acid) & $0.4 \mathrm{mg} \mathrm{cm}^{-2}$ & $407 \mathrm{~mW} \mathrm{~cm}^{-2}$ & 34 \\
\hline 34 & Nano Pt loaded aligned CNTs (ACNT)/Nafion/ACNT & $0.142 \mathrm{mg} \mathrm{cm}^{-2}$ & $560 \mathrm{~mW} \mathrm{~cm} \mathrm{~cm}^{-2}$ & 46 \\
\hline 35 & $\mathrm{Pt} /$ reduced graphene oxide (modified polyol method) & $1.2 \mathrm{mg} \mathrm{cm}^{-2}$ & $128 \mathrm{~mW} \mathrm{~cm}^{-2}$ & 36 \\
\hline
\end{tabular}




\begin{tabular}{|c|c|c|c|c|}
\hline & Description of catalyst \{method of preparation\} & $\begin{array}{l}\text { Catalyst loading } \\
\text { cathode }\end{array}$ & $\begin{array}{l}\text { Fuel cell peak power density; current } \\
\text { density }\end{array}$ & Ref. \\
\hline 36 & $\begin{array}{l}\mathrm{Pt} / \text { graphene oxide } \\
\mathrm{Pt} / \text { reduced graphene oxide }\left(\text { by } \mathrm{N}_{2} \mathrm{H}_{4}, 300{ }^{\circ} \mathrm{C} \mathrm{HT}\right) \\
\left(\mathrm{NaBH}_{4} \text { reduction) }\right.\end{array}$ & $0.2 \mathrm{mg} \mathrm{cm}^{-2}$ & $\begin{array}{l}156 \mathrm{~mW} \mathrm{~cm}{ }^{-2} ; 400 \mathrm{~mA} \mathrm{~cm}{ }^{-2} \\
\sim 110 \mathrm{~mW} \mathrm{~cm}^{-2} ; 250 \mathrm{~mA} \mathrm{~cm}^{-2}\end{array}$ & 37 \\
\hline 37 & $\begin{array}{l}20 \% \mathrm{Pt} / \text { graphene } \\
20 \% \mathrm{Pt} / \text { graphene (citric acid functionalization) }\left(\mathrm{NaBH}_{4}\right. \\
\text { reduction) }\end{array}$ & $0.6 \mathrm{mg} \mathrm{cm}^{-2}$ & $\begin{array}{l}426 \mathrm{~mW} \mathrm{~cm}^{-2} ;<1200 \mathrm{~mA} \mathrm{~cm}^{-2} \\
455 \mathrm{~mW} \mathrm{~cm}{ }^{-2} ; 1200 \mathrm{~mA} \mathrm{~cm}{ }^{-2}\end{array}$ & 38 \\
\hline
\end{tabular}

Among the different forms of carbon, CNTs are especially known for their crystallinity which not only imparts structural uniformity and high electrical conductivity but also assures stability of the nanomaterial. ${ }^{47-50}$ Other exciting properties include high surface area, high thermal conductivities, extraordinary strength, and resilience. ${ }^{51-56}$ These characteristics, if used in a proper manner, can prove highly functional for improving the performance of a fuel cell catalyst. CNTs are being used increasingly in a variety of fuel cell components including bipolar plate, ${ }^{57} \mathrm{GDL},{ }^{58}$ and carbon paper. ${ }^{59}$ Large quantities of CNTs are produced commercially using the chemical vapor deposition method at competitive cost for industrial applications.

The properties of CNTs as a catalyst vary greatly with any change in their structure and purity, which in turn are found to vary largely from batch to batch with even a slight change in processing parameters. Catalyst concentration, gas flow rate, temperature, feed time, and size of reaction zone have been found to affect the properties of MWCNTs developed using the CVD method. ${ }^{60-62}$

In this regard, one of our recent studies clearly signifies the role of heat treatment in improved properties and structural uniformity achieved for MWCNTs.$^{63}$ Highly purified MWCNTs (h-CNTs) were employed as a Pt support, and compared with pristine ones.

This is in contrast to most of the previously reported studies, in which CNTs were usually treated with acid, to introduce some functional groups and provide nuclei sites for $\mathrm{Pt}$ loading. ${ }^{13,21,22,29,30,32-34}$ However, the walls of CNTs are quite inert structures and functionalization only takes place at the ends/ edges. ${ }^{64}$ Thus, in the case of functionalized CNTs, the desired covalent linkages with Pt can only be formed at the tube ends. Moreover, functionalization introduces defects into the pure carbon structure thus affecting its stability and uniformity, which in turn deteriorates its efficiency as a catalyst support.

In this study, to decrease the size of the Pt nanoparticles, the reduction was carried out by a polyol process in the presence of nitrogen using MWCNTs as the support. The study is further supported by exhaustive physical and electrochemical characterizations, which demonstrates how the purity of the support, and the variation in the $\mathrm{pH}$ of reaction media determines the catalytic behavior of the nanocomposite.

An exceptionally high performance of the Pt supported on purified MWCNTs with a peak power density of unit PEM fuel cell of $818 \mathrm{~mW} \mathrm{~cm}^{-2}$ (with $0.25 \mathrm{mg} \mathrm{cm}^{-2}$ platinum loading) was achieved and, to the authors' knowledge, this is the highest reported performance (with a Pt catalyst loaded on MWCNTs as support) to date. This result is credited to (i) purified CNTs which act as an effective and stable catalyst support by providing uniform reaction sites and lower binding of reactants with the inert CNT walls; and (ii) attachment of Pt onto the CNT surface via the formation of coordinate complex as shown by the probable reaction mechanism. Complex ion formation not only stabilizes the Pt NP, but also reduces the chances of its agglomeration. Furthermore, to ascertain the number of electrons involved in the process, along with the $\mathrm{K}-\mathrm{L}$ equation, an entirely new approach to scavenging of the peroxide, if formed during the ORR, by a suitable antioxidant has been undertaken.

\section{Experimental}

\subsection{Synthesis of platinized carbon nanotubes (Pt/CNTs)}

Commercially available Nanocyl 7000 multiwalled CNTs with diameter in the range of $20-30 \mathrm{~nm}$ and aspect ratio $>1000$ were employed as catalyst substrate. Ethylene glycol (EG) and hexachloroplatinic acid $\left(\mathrm{H}_{2} \mathrm{PtCl}_{6} \cdot 6 \mathrm{H}_{2} \mathrm{O}\right)(99 \%$ pure $)$ were procured from Merck Ltd. and Acros Organics, respectively, and used as supplied.

Pristine CNTs were dispersed in EG via ultra-sonication. A $0.01 \mathrm{M}$ solution of $\mathrm{H}_{2} \mathrm{PtCl}_{6}$ was added to the dispersed CNTs while keeping the ratio of Pt: CNT as $10: 90$ by weight. The solution made after the addition of platinum was distributed in three separate reaction flasks and their pHs were adjusted to 2 , 7 and 11. These reaction mixtures were further refluxed at 140 ${ }^{\circ} \mathrm{C}$ for $3 \mathrm{~h}$ under a constant flow of nitrogen. This process reduces the platinum salt and immobilizes Pt nanoparticles (NPs) on the surface of pristine CNTs, thus forming Pt/CNT nano-composites. The catalyst samples prepared while refluxing in acidic (pH 2), neutral ( $\mathrm{pH} 7)$ and alkaline ( $\mathrm{pH}$ 11) media were designated as samples $\mathrm{N} 1, \mathrm{~N} 2$, and $\mathrm{N} 3$, respectively.

Nanomaterials favor a self-purification process such that the impurities and intrinsic material defects move near the surface on thermal annealing. ${ }^{65,66} \mathrm{Hence}$, in another set of experiments, the MWCNTs were heated to $2200{ }^{\circ} \mathrm{C}$ in an inert atmosphere to form h-CNTs. Heat treatment has been proved to be an efficient means to remove the catalyst impurities and increase the degree of graphitization in CNT structure. ${ }^{63,67,68}$

The Pt/h-CNT nanocomposites were synthesized in a similar way to that described above, while keeping the ratio of $\mathrm{Pt}: \mathrm{h}$ CNT, as 10:90 by weight. The samples prepared in acidic, 


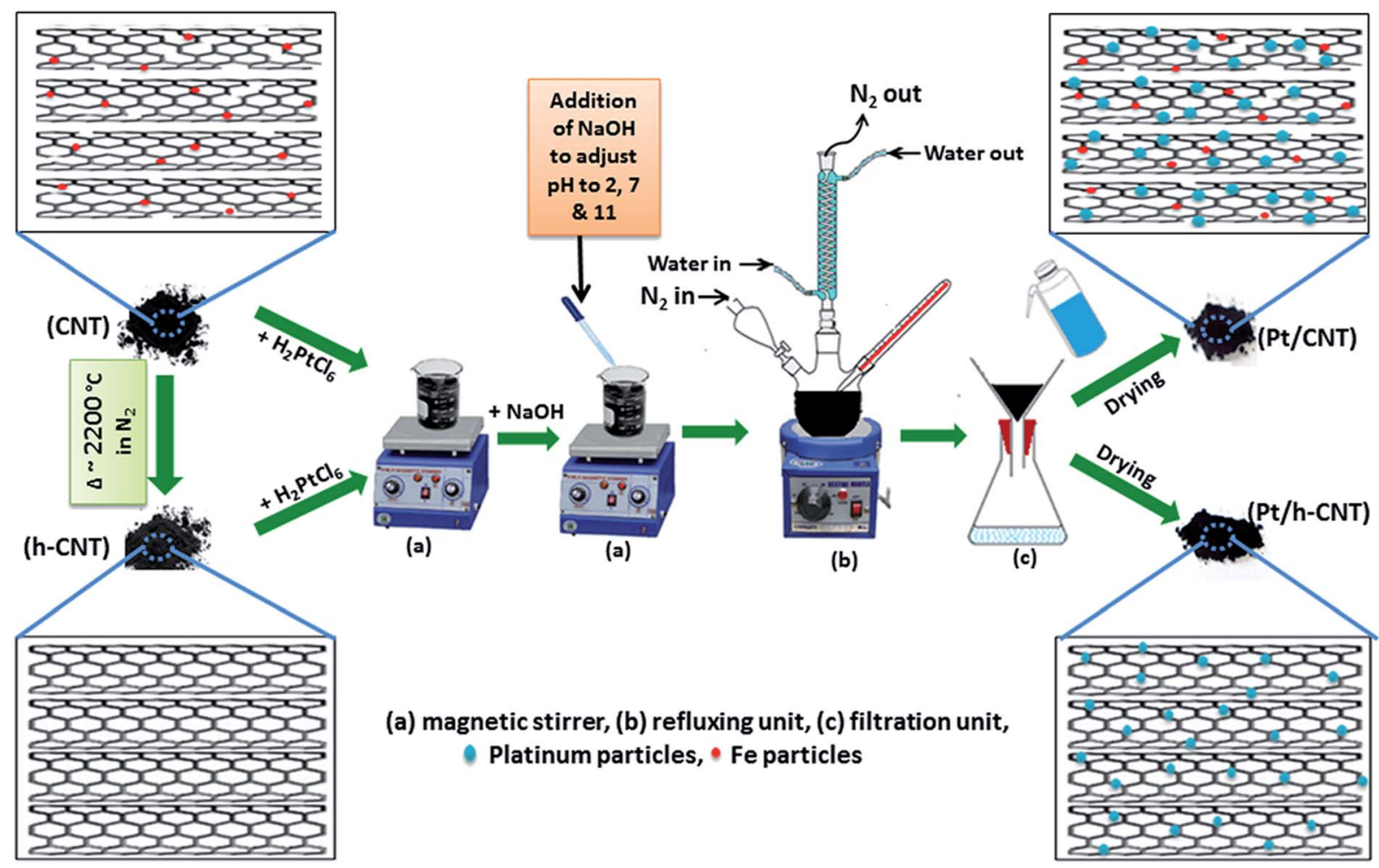

Fig. 1 Schematic of the process of catalyst development.

neutral and alkaline media were designated as M1, M2, and M3 respectively. Fig. 1 displays the schematic of the above procedure.

\subsection{Material characterization}

XRD was performed on a Rigaku powder X-ray diffractometer model: XRG $2 \mathrm{KW}$ using $\mathrm{Cu} \mathrm{K} \alpha$ radiation. The mean crystallite size and lattice parameters were calculated from line broadening and $d$-spacing using the Debye Scherrer formula. Thermal stability and platinum loading in samples were estimated by TGA. The measurements were carried out on a TGA/DSC 1600 by Mettler Toledo at a constant heating rate of $10{ }^{\circ} \mathrm{C} \mathrm{min}^{-1}$ in air. The purity of the prepared samples was ascertained from Raman analysis. Raman spectroscopy was carried out using a Renishaw InVia Reflex Micro Raman spectrometer equipped with CCD detector at room temperature and in air. A green laser (excitation line $514 \mathrm{~nm}$ ) was used to excite the samples. Five scans per sample were recorded, wherein the samples were exposed to laser power of $25 \mathrm{~mW}$ for $10 \mathrm{~s}$. The size and distribution of platinum particles on CNTs was determined by high resolution transmission electron microscopy (HR-TEM).

\subsection{Electrochemical characterizations}

The electrochemical measurements were performed using a Biologic instrument, VSP model with EC-Lab software. CV and LSV measurements were carried out by a conventional three electrode method with $0.5 \mathrm{M}$ perchloric acid (PA) as the electrolyte. In RDE measurements a dilute solution of $\mathrm{HClO}_{4}$ is the standard electrolyte that stimulates the perfluorosulfonic acid ionomer (low anion adsorption of bound sulfonic acid groups). ${ }^{69}$ Some literature also describes use of $\mathrm{H}_{2} \mathrm{SO}_{4}$ as electrolyte. However, the activity of Pt catalyst is lower in $\mathrm{H}_{2} \mathrm{SO}_{4}$ because Pt surfaces are highly susceptible to the adsorption of the $\mathrm{HSO}_{4}{ }^{-}$and $\mathrm{SO}_{4}{ }^{2-}$ ions. ${ }^{70,71}$

Saturated calomel electrode (SCE), platinum wire and synthesized catalyst were used as reference, counter, and working electrodes, respectively. In the CV experiments the electrolyte was purged with $\mathrm{N}_{2}$. The working electrode was cycled between -0.25 and $0.8 \mathrm{~V}$ with respect to the reference electrode at a sweep rate of $50 \mathrm{mV} \mathrm{s}^{-1}$ for 50 cycles to obtain a stable curve. LSV was measured in rotating disc electrode (RDE) apparatus with the electrolyte saturated with $\mathrm{O}_{2}, 5 \mathrm{mV} \mathrm{s}^{-1}$ sweep rate, and speed of the rotating disk fixed at 400, 800, $1200,1600,2000$, and $2400 \mathrm{rpm}$.

\subsection{MEA fabrication and single cell assessment}

Toray TGP-H-120 carbon paper (15 wt\% teflonised) of $0.37 \mathrm{~mm}$ thickness was used as the backing layer. For preparing the gasdiffusion layer (GDL), carbon powder (Vulcan XC-72R obtained from Cabot Corporation, USA), polytetrafluoroethylene (PTFE), and cyclohexane were mechanically mixed in an ultrasonic mixer, and the viscous mixture was coated onto the wet-proofed carbon paper such that the carbon and PTFE loadings were maintained at 1.5 and $0.225 \mathrm{mg} \mathrm{cm}^{-2}$, respectively. The GDL thus obtained was sintered in the muffle furnace at $350{ }^{\circ} \mathrm{C}$ for 30 min. The next step was to prepare the thin catalyst layer. The cathode and anode catalyst slurries were prepared by mixing the 
catalyst with $30 \mathrm{wt} \%$ and $7 \mathrm{wt} \%$ of Nafion solution, respectively. For fabrication of the membrane-electrode assembly (MEA), the catalyst slurry was coated onto the GDL. The catalyst loading was $0.25 \mathrm{mg} \mathrm{cm} \mathrm{cm}^{-2}$ for both the cathode and anode and an effective electrode area of the PEMFC was $4 \mathrm{~cm}^{2}$. The MEA was fabricated with Nafion 212 membrane by sandwiching it between the two electrodes followed by hot-pressing at $130{ }^{\circ} \mathrm{C}$ for $3 \mathrm{~min}$ at a pressure of $20 \mathrm{~kg} \mathrm{~cm}{ }^{-2}$. The performances of MEAs were evaluated using a conventional fuel cell fixture with parallel serpentine flow-field machined on graphite bipolar plates. The cells were tested at $60{ }^{\circ} \mathrm{C}$ with flow rates of hydrogen and oxygen gases fixed at $200 \mathrm{ml} \mathrm{min}{ }^{-1}$ and $300 \mathrm{ml} \mathrm{min}^{-1}$ at the anode and cathode, respectively. Measurements of cell potentials with varying current densities were conducted galvanostatically using model-LCN4-25-24/LCN 50-24 procured from Bitrode Instruments (USA).

\section{Results and discussion}

\subsection{X-ray diffraction analysis}

The XRD patterns of Pt/CNTs (samples N1, N2 and N3) and Pt/hCNTs (samples M1, M2 and M3) are shown in Fig. 2(a) and (b), respectively. The diffraction peak obtained at around $25.5^{\circ}$ is attributed to the graphite crystallographic plane (002) of carbon, with $d$-spacing in the range of 3.4-3.5 $\AA$. The introduction of a (100) plane of carbon in the samples prepared with h-CNTs probably indicates improved crystallization and the onset of inter-planar site correlation of the CNT structure.

The face centered cubic (fcc) structure of $\mathrm{Pt}$ is verified by the presence of diffraction peaks at nearly $40^{\circ}, 46.3^{\circ}$ and $67.4^{\circ}$, which can be assigned to the (1 111$),\left(\begin{array}{lll}2 & 0 & 0\end{array}\right)$ and ( $\left.\begin{array}{lll}2 & 2 & 0\end{array}\right)$ planes of $\mathrm{Pt}$, respectively. The FWHM of the different samples and the corresponding crystallite size was calculated according to the Debye Scherrer formula $\tau=\frac{k \lambda}{\beta \cos \theta}$ (given as ESI in Table S1(a and $b) \dagger$ ). Here $\tau$ is the mean size of the crystalline domain, $k$ is the dimension less shape factor with value close to unity, $\beta$ is the FWHM, i.e. line broadening at half the maximum intensity, and $\theta$ corresponds to Bragg angle.

The mean crystallite sizes for the nanocomposites N1, N2, and N3 were found to be $3.95,2.68$, and $3.51 \mathrm{~nm}$, while those of M1, M2, and M3 were found to be $5.10,2.55$, and $3.84 \mathrm{~nm}$, respectively. Thus, with varying $\mathrm{pH}$ conditions the crystallite size changes. Initially, there is a decrease in the crystallite with increase in $\mathrm{pH}$ from 2 to 7 ; however, with further increase in $\mathrm{pH}$ (from 7 to 11), the crystallite size increases. These results were further confirmed by TEM images as shown in Fig. 3. The average $\mathrm{Pt}$ particle size in the samples was also calculated from several randomly selected areas in HR-TEM images and was found to be smaller for samples N2 and M2 (Fig. 3(d) and (h)). This could be because of the probable spatial arrangement of ligand (ethylene glycol) around the platinum in Pt-CNT nanocomposite during the reduction reaction under varied $\mathrm{pH}$ conditions (i.e. acidic, neutral, and alkaline mediums).

A possible mechanism for this is given in Fig. 4. In acidic medium, ethylene glycol (EG) (which is already slightly acidic in nature) attains a trans configuration because of partial
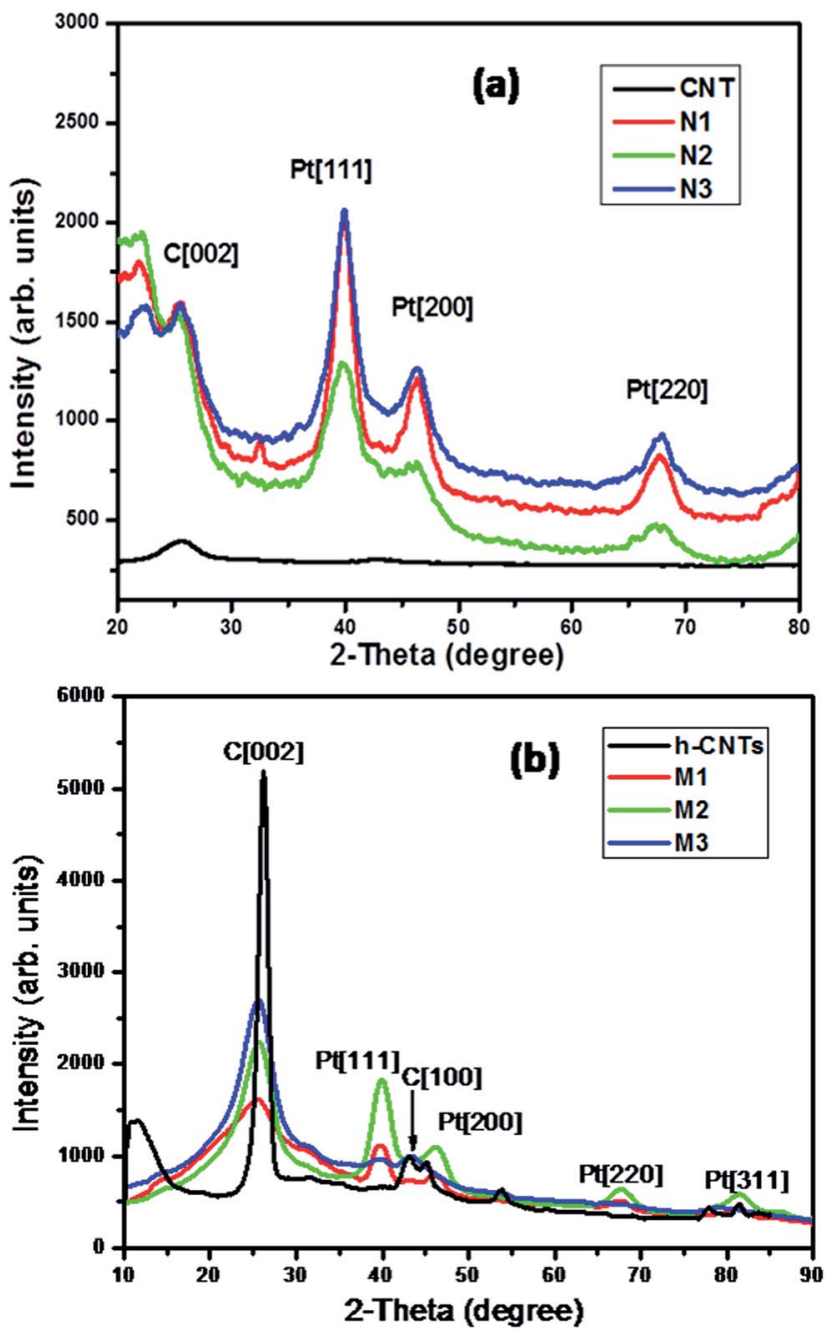

Fig. 2 X-ray diffraction analysis of (a) CNTs, Pt/CNTs samples, (b) hCNTs, Pt/h-CNTs samples.

hydrogen bonding with the $\mathrm{H}^{+}$ions present in the medium. This trans configuration of EG may facilitate the tetradentate bonding with platinum. Moreover, the reduction is carried out in nitrogen atmosphere and nitrogen being a good ligand may also incline itself to form a shell around reduced Pt by donating its lone pair of electrons. However, in neutral medium there are no free ions available, so there is maximum probability of cis confirmation of EG. To stabilize Pt, the EG may form a chelatetype complex around the Pt thus yielding better stability. In addition, the inert atmosphere does not assist formation of glyconate ions from the EG.

When the reaction is carried out in alkaline medium, hydroxyl ions may try to initiate formation of glyconate ions from EG and hinder the glyconate ions from stabilizing Pt; as a result, these ions can adhere to CNT via van der Waals interaction, rendering the nanocomposite more hydrophilic. Consequently there will be a ligand competition amid nitrogen $\left(\mathrm{N}_{2}\right)$ and glyconate ions $\left(\mathrm{OH}-\mathrm{CH}_{2} \mathrm{O}^{-}\right)$, and nitrogen being a soft ligand has more probability of forming a shell around the reduced $\mathrm{Pt}$ and stabilizing it. We attempted to confirm the 

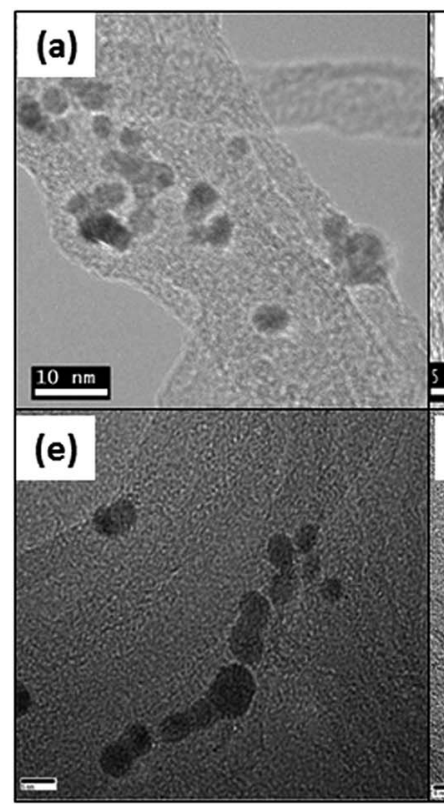

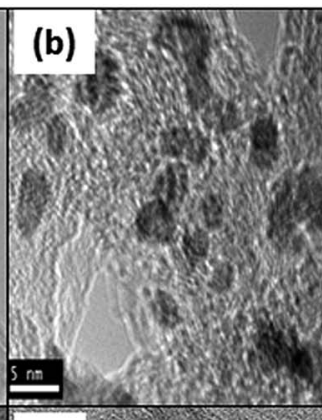

(f)

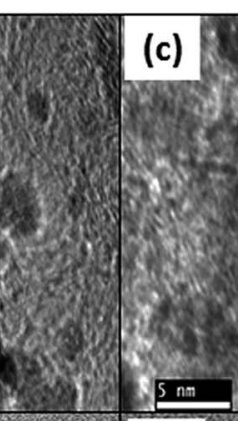

(g)

Fig. 3 TEM micrographs (a), (b), (c) for N1, N2, N3, respectively, and (e), (f), (g) for M1, M2, M3, respectively, (d) and (h) are the particle size distribution curves for $\mathrm{N} 2$ and $\mathrm{M} 2$, respectively.

proposed mechanism by dispersing individual samples (M1, M2, and M3) in water. Fig. 5 shows that sample M3 was fully dispersed in the water, but samples M1 and M2 were not. It should be noted here that the hydrophilicity of CNT is induced in alkaline medium because EG is available freely on CNT walls to interact with water. Nitrogen shell formation around Pt may also be a reason for increase in the apparent size of the $\mathrm{Pt}$ nanoparticles in acidic and alkaline media.

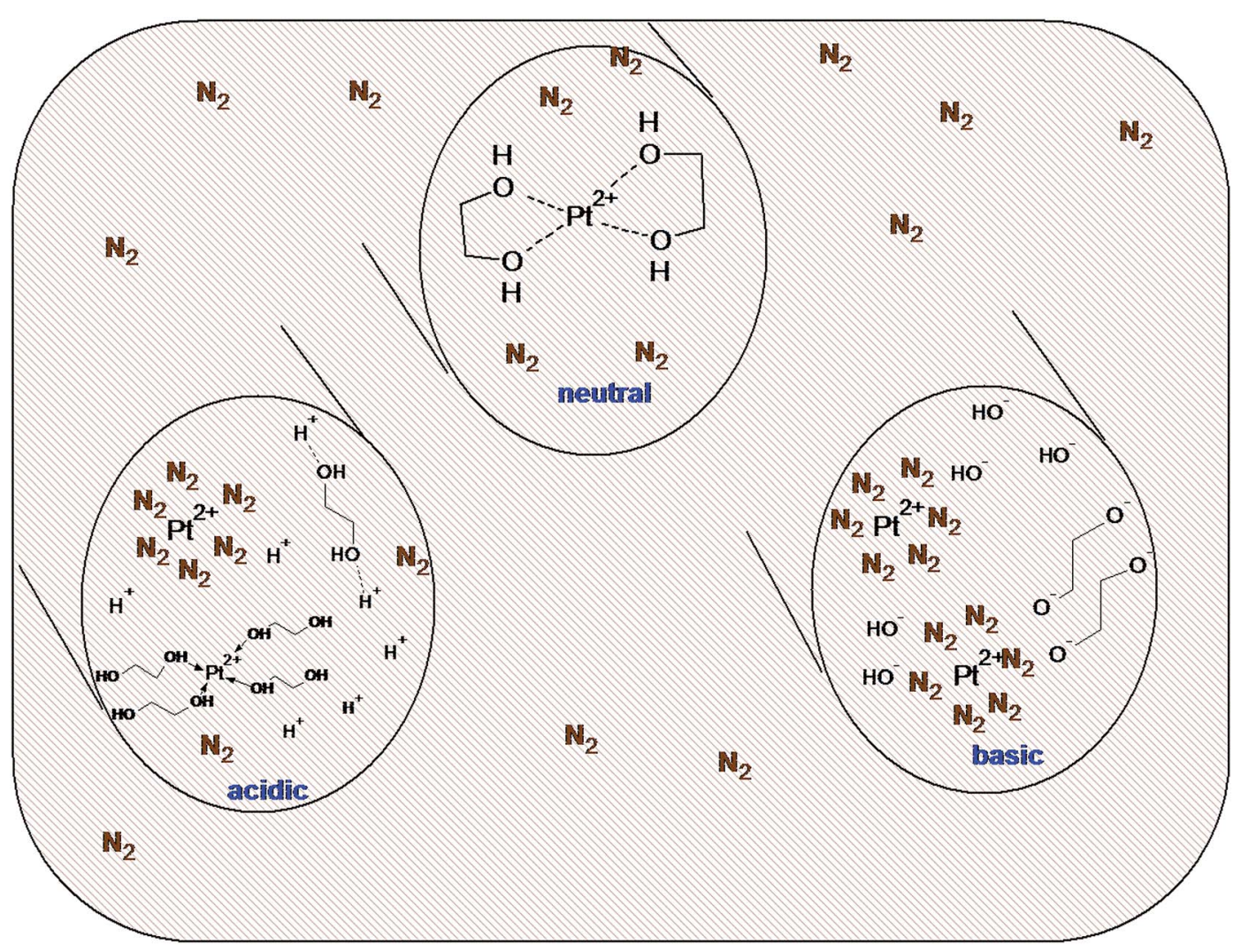

Fig. 4 Plausible reaction mechanism when the Pt reduction is carried out in acidic, neutral, and alkaline mediums. 


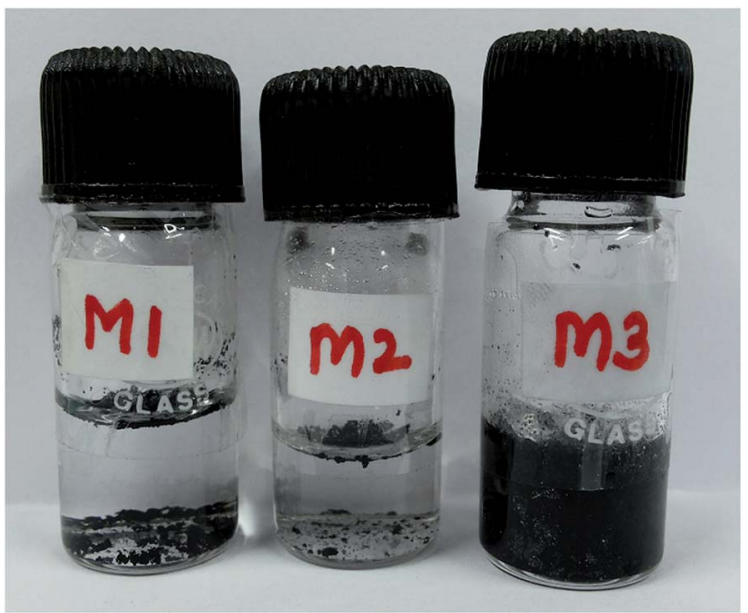

Fig. 5 Photograph with samples M1, M2, and M3 dispersed in water and ultrasonicated for $1 \mathrm{~min}$, showing hydrophilicity of sample M3.

\subsection{Thermal gravimetric analysis}

TGA was carried out to confirm the amount of Pt incorporated in the nanocomposites. The TGA curves of pristine CNT, Pt/CNT nanocomposites and $\mathrm{h}-\mathrm{CNT}, \mathrm{Pt} / \mathrm{h}-\mathrm{CNT}$ nanocomposite samples prepared under different $\mathrm{pH}$ are shown in Fig. 6(a) and (b). Pristine CNT shows a residue of about $8.56 \%$, which is most likely because of the presence of metal $(\mathrm{Co}, \mathrm{Ni})$ oxides used during the CNT synthesis. For the Pt/CNT samples N1, N2 and $\mathrm{N} 3$, the residual content is $19.25 \%, 20.51 \%$ and $20.09 \%$, respectively, indicating that almost all platinum (i.e. $~ 10 \%$ ) is reduced on the CNT surface. TGA for h-CNT (without Pt) shows no residue, which clearly indicates that heat treatment effectively removes the catalytic impurities, and also removes the inherent flaws in the CNT structure. ${ }^{67}$ Thermal decomposition of h-CNTs takes place at around $750{ }^{\circ} \mathrm{C}$, much higher than decomposition of pristine CNTs $\left(610{ }^{\circ} \mathrm{C}\right)$. The increase in the thermal stability of the former is a measure of improved CNT structure with reduced defects. This can be seen in the TEM micrographs of h-CNTs (Fig. 7(b)), which depict a marked improvement in the crystalline structure compared with pristine CNTs (shown in Fig. 7(a)). Long-range ordering of microstructure is also clearly visible from the TEM images.

For the Pt/h-CNT samples M1, M2 and M3, the residual content is $10.44,11.36$, and $9.29 \%$, respectively, indicative of $\sim 10 \%$ Pt reduced on the CNT surface.

The thermal stability of the nanocomposites further reduces compared with CNTs/h-CNTs. This is because (i) the metal NPs act as defects and catalyze the oxidation process; and (ii) there is a probability that defects are also introduced in the nanotube structure during the refluxing process.

\subsection{Raman spectroscopy}

These results were further confirmed by Raman spectroscopy which is an important tool to yield information about the purity and defects present in the carbon structure. Fig. 8(a) and (b) shows the Raman spectra of the CNTs, Pt/CNT nanocomposites
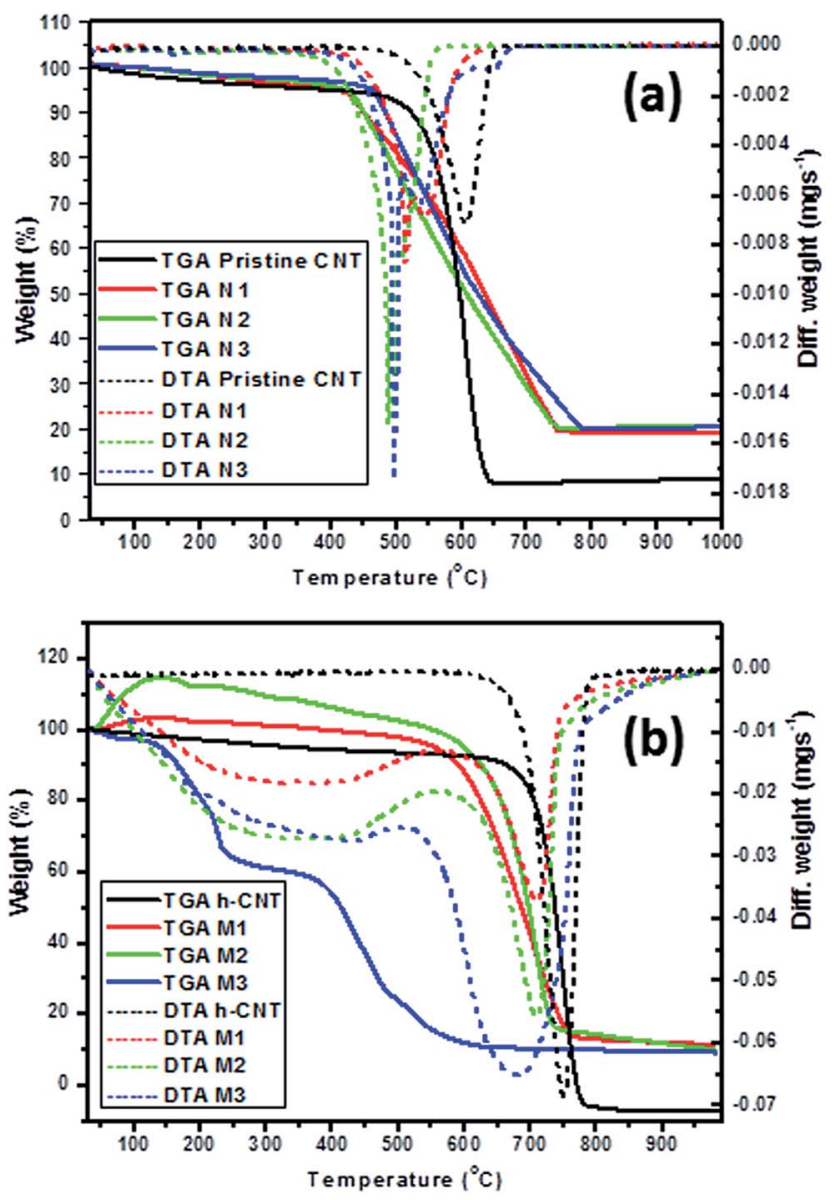

Fig. 6 TGA and DTA curves of (a) CNTs, Pt/CNT nanocomposites, and (b) h-CNTs, Pt/h-CNT nanocomposites.

and h-CNTs, Pt/h-CNT nanocomposites. Three bands: D (defect/ disorder induced) band, G (graphite like) band, and $\mathrm{G}^{\prime}$ (second order harmonic to $\mathrm{D}$ ) band were identified in the spectra. The $\mathrm{D}$ band is a characteristic of defects in the hexagonal carbon structure, vacancies, catalyst impurity, etc. The G band originates from in-plane tangential stretching of carbon-carbon bonds in grapheme sheets and is a measure of graphitization of the samples. The $\mathrm{G}^{\prime}$ band corresponds to the second-order harmonic of the D mode and is a measure of the defects in the stacking sequence. The intensities of the bands were determined as the area under the spectral curve. There is almost

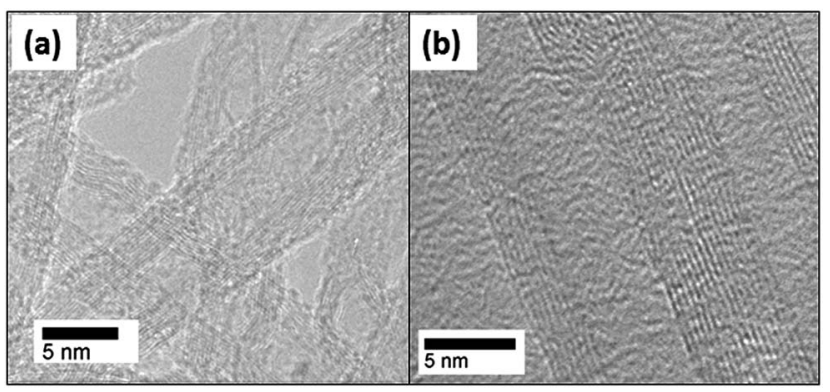

Fig. 7 TEM micrographs of (a) pristine CNT and (b) h-CNT sample. 
$70 \%$ reduction in the relative intensity of the $\mathrm{D}$ band, i.e. $I_{\mathrm{D}} / I_{\mathrm{G}}$, for h-CNTs over the pristine ones. This again indicates longrange ordering in the hexagonal lattice owing to an increase in purity and removal of the structural defects with heat treatment. For both the experimental series the $I_{\mathrm{D}} / I_{\mathrm{G}}$ increases for the nanocomposites. This is because of the addition of $\mathrm{Pt}$ (which acts as a defect in the pure carbon structure) and also because of the stresses generated on the hexagonal layer of CNTs by its incorporation.

There is almost $100 \%$ increase in the relative intensity of the $\mathrm{G}^{\prime}$ band, i.e. $I_{\mathrm{G}^{\prime}} / I_{\mathrm{G}}$, for h-CNTs compared with pristine ones. This indicates the development of long-range stacking order in samples, as also indicated by the XRD spectra.

Before employing the actual catalyst, the support material was evaluated for the electrochemical studies. The CV and LSV curves for CNT and h-CNT samples (as shown in Fig. 9(a) and (b)) demonstrate a high value of diffusion current and higher charges associated with h-CNTs compared with pristine CNTs. This is probably because the process of heat treatment removes the defects and functionalities from the CNT surface that may otherwise result in the loss of useful current because of

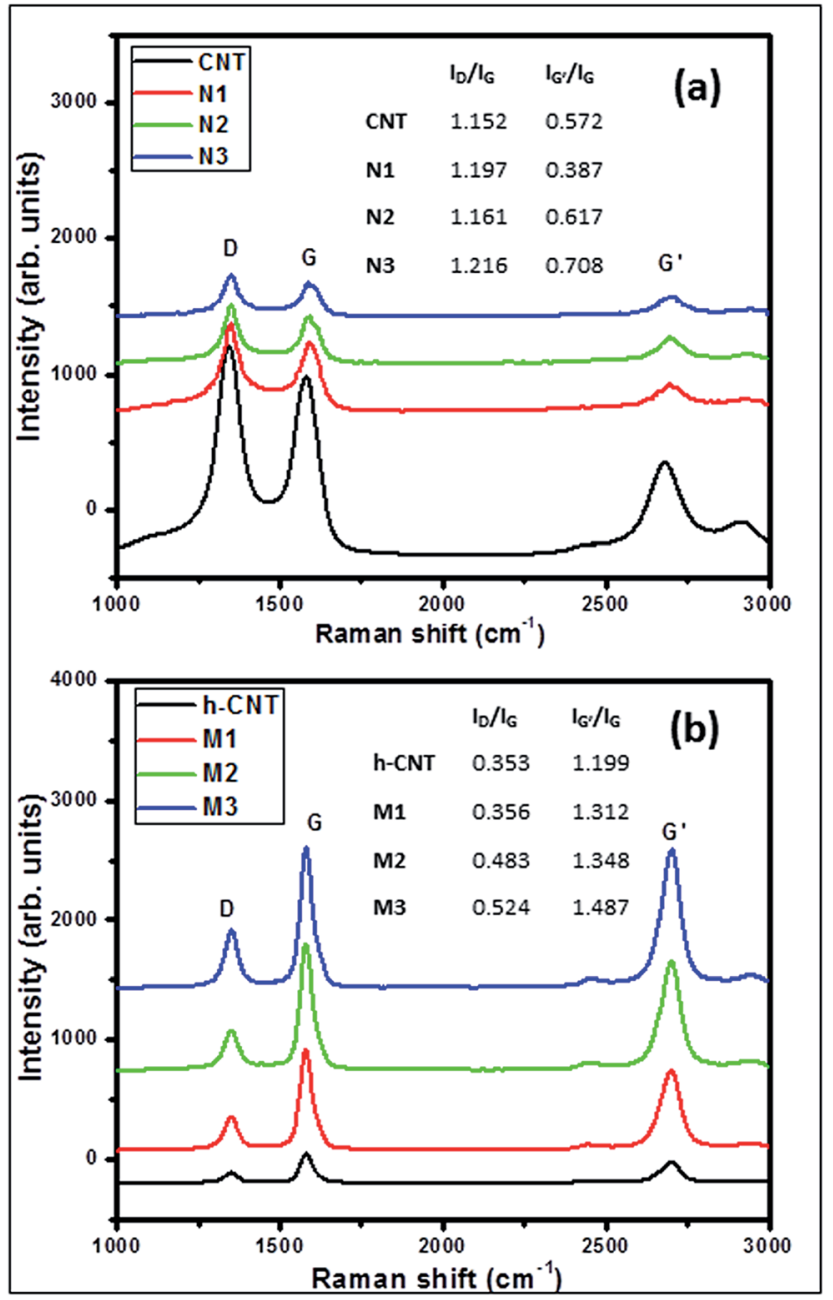

Fig. 8 Raman spectra of (a) CNTs, Pt/CNT nanocomposites, and (b) hCNTs, Pt/h-CNT nanocomposites. unnecessary side reactions. As shown in Fig. 7(b) (and represented in Fig. 1), h-CNTs have structural uniformity and therefore have higher probability for better dispersion of the Pt metal (active sites). Furthermore, the heat treatment would improve the adsorption properties and provide fast diffusion of reactants and products from the surface sites with maximum contribution to the catalytic activity besides acting as a catalyst support. Fig. 9(b) also shows peaks of hydrogen adsorption and desorption. This is probably because the highly crystalline $\mathrm{sp}_{2}$ hybridized structure of the h-CNTs provides mobility to the $\mathrm{p}_{z}$ electron cloud which is vacant and highly reactive. Moreover, hydrogen oxidation is a very fast and straightforward reaction. But, as is clear from Fig. 9, the current density values are very low when only h-CNTs are used and Pt is further incorporated (to form the nanocomposite) to increase the same.

\subsection{Electrochemical studies of the catalyst samples}

3.4.1 Cyclic voltammetry studies. The CV curves of the nanocomposites prepared under different $\mathrm{pH}$ conditions are
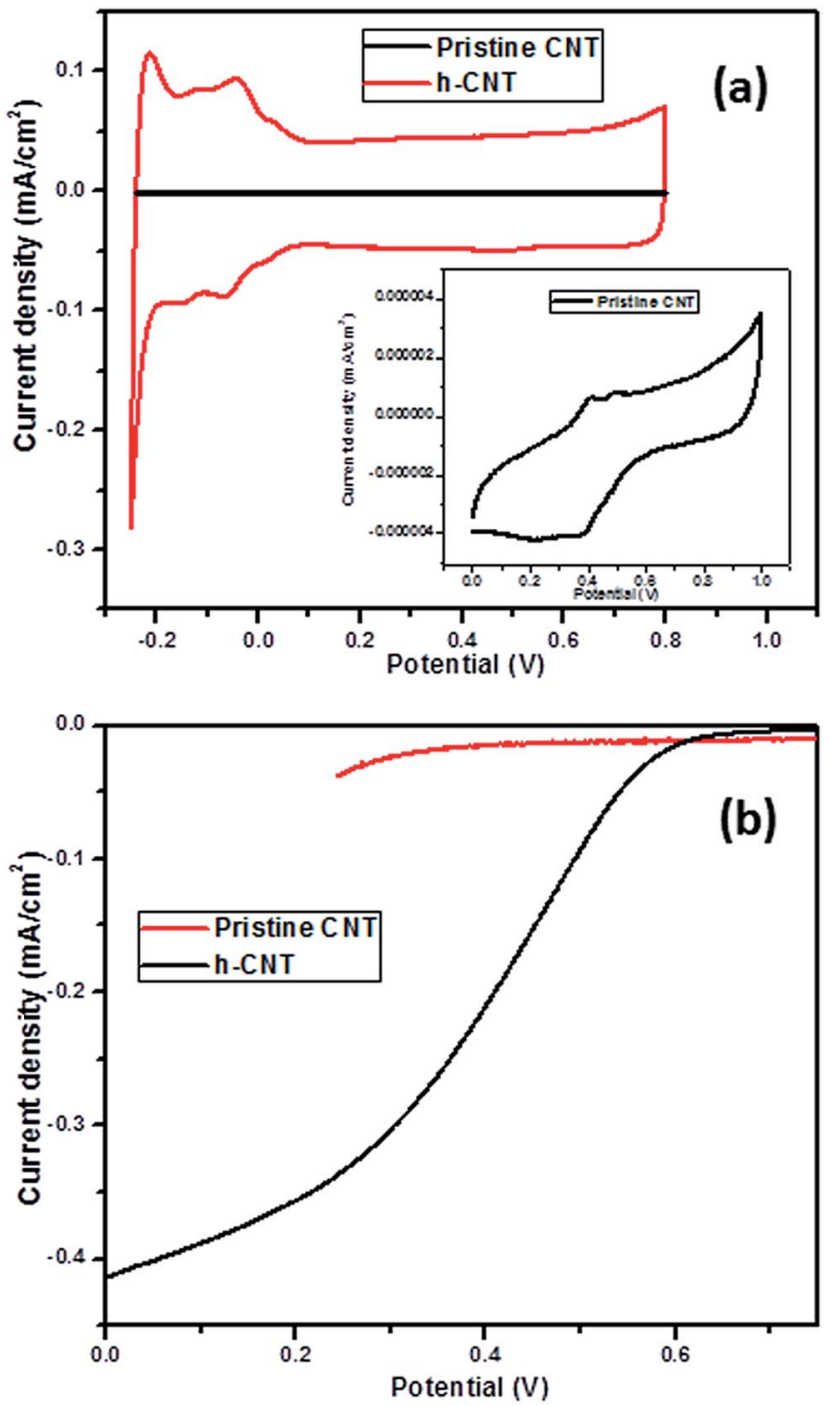

Fig. 9 (a) Cyclic voltammetry and (b) linear sweep voltammetry curves of the pristine and purified CNTs in $0.5 \mathrm{M} \mathrm{HClO}_{4}$ solution. 
shown in Fig. 10(a) and (b). These exhibit typical characteristics of crystalline $\mathrm{Pt}$ electrodes in the hydrogen adsorptiondesorption regions. The electro chemical surface area (ECSA) was calculated from the integrated charge associated with the hydrogen adsorption region that is based on a monolayer hydrogen adsorption on platinum giving a measure of the HOR. ECSA for N1, N2, and N3 were found to be 58, 60, and $38 \mathrm{~m}^{2} \mathrm{~g}^{-1}$, and those for samples M1, M2, and M3 were 77.84, 165.09, and $87.16 \mathrm{~m}^{2} \mathrm{~g}^{-1}$. The increase in the ECSA of the hydrogen adsorption peak for samples N2 and M2 can be correlated to a decrease in size of the deposited Pt NPs with uniform distribution that leads to its effective utilization.

3.4.2 Linear sweep voltammetry studies. The ORR kinetics of the nanocomposite samples were investigated by LSV curves as shown in Fig. 11(a) and (b). From the LSV curves, the onset potential was measured, which gives the potential at which the ORR initiates. This was found to be highest for sample M2. High mid wave potential for M2 further reflects low binding energy of
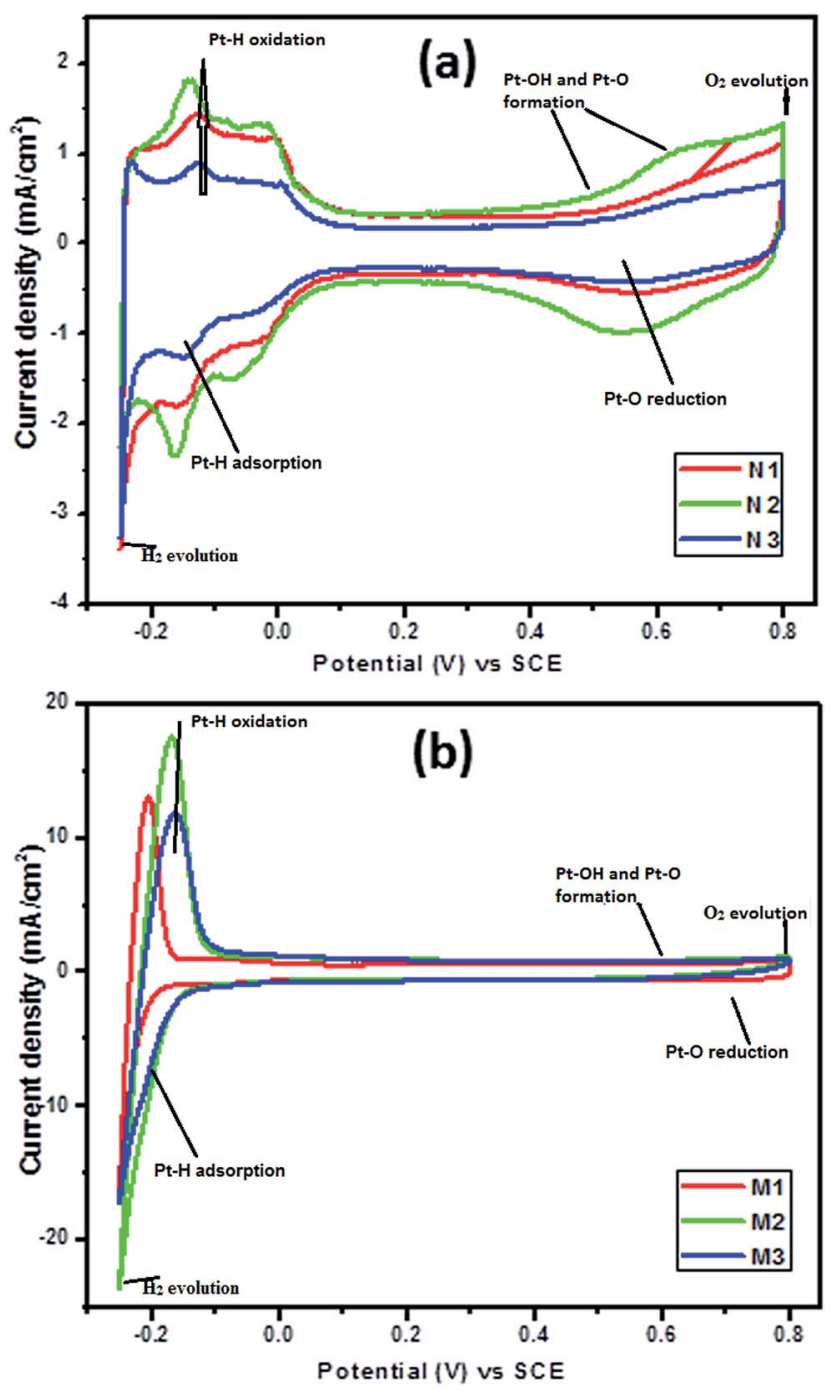

Fig. $10 \mathrm{CV}$ curves recorded for (a) Pt/CNT, and (b) Pt/h-CNT nanocomposites, in $\mathrm{N}_{2}$ purged $0.5 \mathrm{M} \mathrm{HClO}_{4}$ solution showing different regions. the catalyst surface with the reactants, which in turn implies fast catalytic activity as the catalyst surface is quickly available for reducing more $\mathrm{O}_{2} \cdot{ }^{36}$ To estimate the number of electrons involved in the ORR, LSV was carried out at different rotating speeds varying from 400 to $2400 \mathrm{rpm}$ (as shown in the ESI Fig. S1†). The diffusion limiting current increases proportionally with the rotating speed because of an increase in the diffusion of reactant species while making reactants available on the electrode surface.

The values obtained were applied to the Koutecky-Levich equation:

$$
\frac{1}{i}=\frac{1}{i_{\mathrm{k}}}+\frac{1}{i_{\mathrm{d}}}=\frac{1}{i_{\mathrm{k}}}+\frac{1}{B \omega^{\frac{1}{2}}} .
$$

Here $B=\frac{0.62 n F A C_{\mathrm{o}}{ }^{2} D_{\mathrm{O}_{2}}{ }^{3 / 2}}{\eta^{1 / 6}}, i$ is the experimentally determined current, $i_{\mathrm{k}}$ is the kinetic current, $i_{\mathrm{d}}$ is the diffusion-limited current, $n$ is the number of electron transferred, $F$ is Faraday constant, $A$ is the geometric area of the electrode, $D_{\mathrm{O}_{2}}$ is the diffusion coefficient of $\mathrm{O}_{2}$ in the electrolyte and $\eta$ is the viscosity
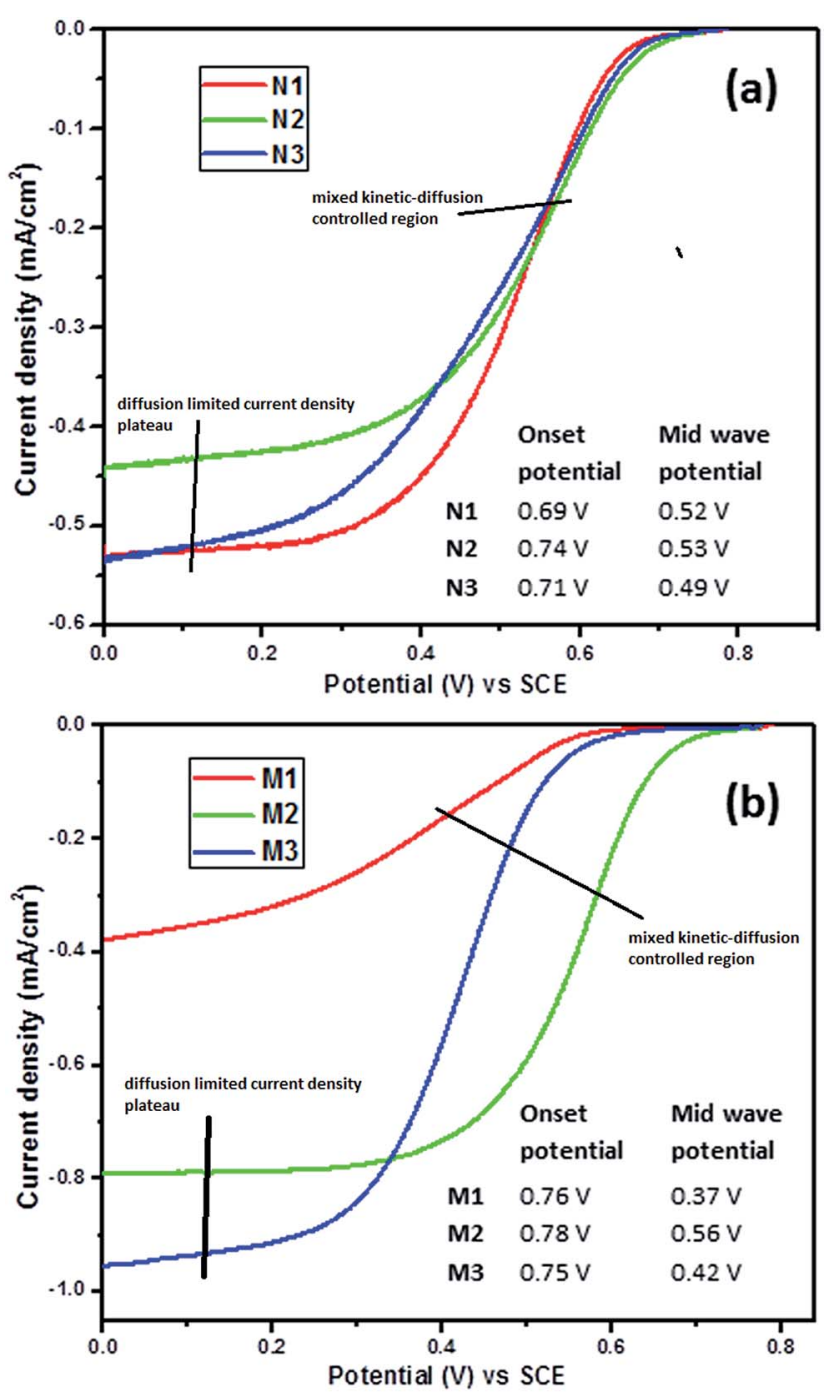

Fig. 11 LSV curves recorded for (a) Pt/CNT, and (b) Pt/h-CNT nanocomposites, in $\mathrm{O}_{2}$ purged $0.5 \mathrm{M} \mathrm{HClO}_{4}$ solution. 


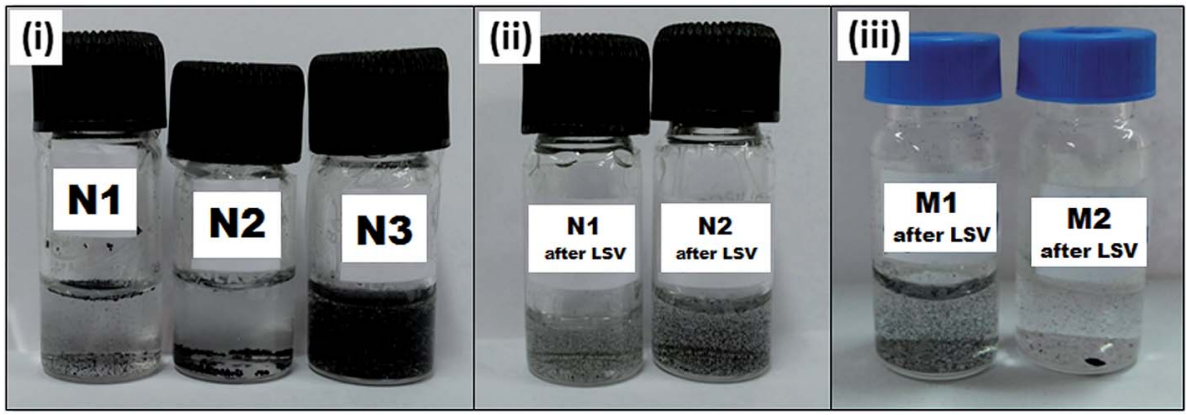

Fig. 12 Photographs of (i) catalyst sample N1, N2, (ii) catalyst sample N1, N2 scraped from the electrode after the LSV studies, and (iii) catalyst sample M1, M2 scraped from the electrode after the LSV studies.

of electrolyte. A linear plot of $i^{-1}$ versus $\omega^{-1 / 2}$ has a slope of $1 /$ $0.62 n F A C_{\mathrm{o}}{ }^{2} D_{\mathrm{O}_{2}}{ }^{3 / 2} \eta^{-1 / 6}$ (Fig. $\mathrm{S} 1$ and $\mathrm{S} 2 \dagger$ ). The value of slope and detailed calculations for $n$ for the different samples at given voltages are tabulated in the ESI. $\dagger$ The average value of $n$ for the nanocomposites has been calculated as 3.7, 3.5, and 1.9 for N1, $\mathrm{N} 2$, and N3, and 3.6, 4.1, and 3.5 for M1, M2, and M3, respectively. Thus while sample M2 supports a four-electron reaction for oxygen reduction, a two-electron process is involved for samples N1, N2, M1, and M3. In the case of N3, only a twoelectron process is involved in ORR.

Moreover, according to a previously proposed mechanism, ${ }^{72}$ in the four-electron pathway, $\mathrm{O}_{2}$ is directly reduced to $\mathrm{H}_{2} \mathrm{O}$ (eqn (1)), while in the two-electron path $\mathrm{O}_{2}$ is reduced to $\mathrm{H}_{2} \mathrm{O}$ via peroxide $\left(\mathrm{H}_{2} \mathrm{O}_{2}\right)$ intermediate (eqn (2) and (3)) as shown below. ${ }^{72}$

$$
\begin{gathered}
\mathrm{O}_{2}+4\left(\mathrm{H}^{+}+\mathrm{e}^{-}\right) \rightarrow 2 \mathrm{H}_{2} \mathrm{O} \\
\mathrm{O}_{2}+2\left(\mathrm{H}^{+}+\mathrm{e}^{-}\right) \rightarrow \mathrm{H}_{2} \mathrm{O}_{2} \\
\mathrm{H}_{2} \mathrm{O}_{2}+2\left(\mathrm{H}^{+}+\mathrm{e}^{-}\right) \rightarrow 2 \mathrm{H}_{2} \mathrm{O}
\end{gathered}
$$

A number of computational studies in the literature have highlighted dissociative adsorption of peroxide on the $\mathrm{Pt}$ surface as adsorbed $\mathrm{OH}$ species. ${ }^{72}$

$$
2 \mathrm{Pt}+\mathrm{H}_{2} \mathrm{O}_{2} \rightarrow 2 \mathrm{Pt}(\mathrm{OH})
$$

If the $\mathrm{Pt}(\mathrm{OH})$ is so formed, this should render the catalyst more hydrophilic. N3 and M3 are already hydrophilic, so samples N1, N2, M1, and M2 were collected from the glassy carbon electrode after the LSV studies (in $\mathrm{O}_{2}$ ) and their water solubility was checked. As shown in Fig. 12, while N1, N2, and M1 showed solubility in water, M2 is still insoluble.

3.4.3 Scavenging studies. RRDE (rotating ring disk electrode) is the most popular and widely used method to ascertain the number of electrons involved in oxygen reduction. However, a new, as-yet unreported, approach was used in this study, involving scavenging of the peroxide, if formed, by an antioxidant. A suitable scavenger-like ascorbic acid (AA) can direct the mechanism by blocking the activity of the intermediate peroxide species, which will lead to reduction in the current.

LSV study of the Pt/h-CNT series (samples M1, M2, and M3) was carried out in the following order and the results are shown in Fig. 13(a)-(c).

(i) With $0.5 \mathrm{M}$ perchloric acid as electrolyte (PA)

(ii) With $0.5 \mathrm{M}$ perchloric acid and $0.12 \mathrm{mM}$ ascorbic acid mixed in the ratio of $1: 1$ as electrolyte (PA $+\mathrm{AA})$

(iii) Repeated study with perchloric acid (PA-r)

As observed in Fig. 13(a) and (c), the presence of AA decreases the output current for samples M1 and M3, which gives a clear indication of the formation of peroxides, which in turn are scavenged by AA. When the sample was repeated in perchloric acid (PA), a further decrease in current was observed because of the catalyst sites being blocked by AA. Conversely, in the case of sample M2, the current remains the same even when AA is added to the electrolyte. This signifies a four-electron process where no such peroxide intermediates are formed.
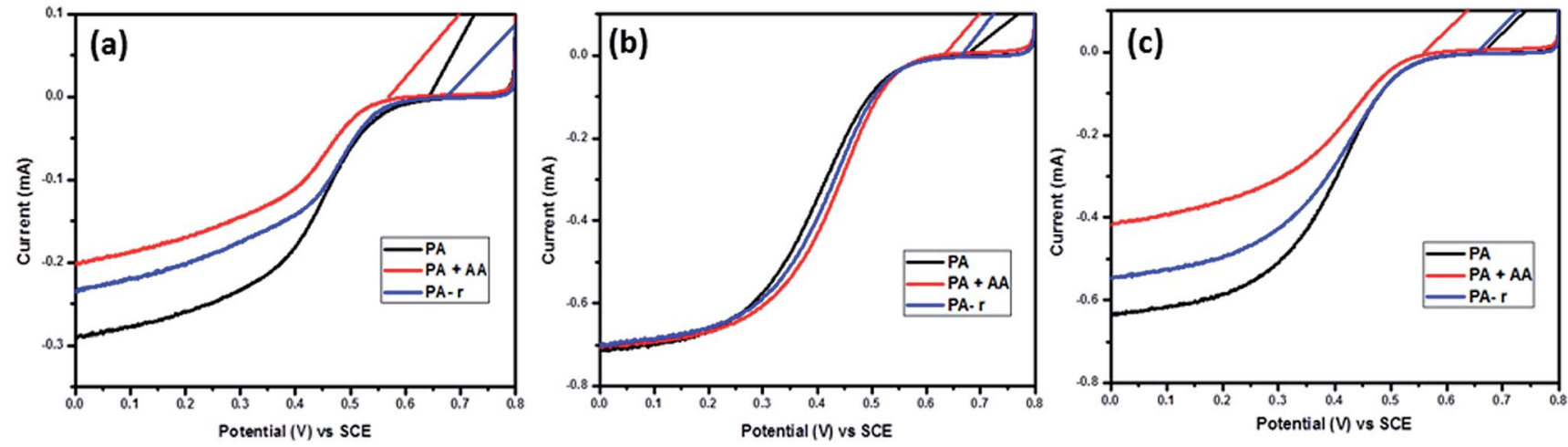

Fig. 13 (a), (b) and (c) Scavenging studies of M1, M2 and M3 samples respectively. 
And, therefore, the reaction remains unaffected even in the presence of AA. Furthermore, when the voltammetry studies were repeated with perchloric acid (i.e. PA-r), the curve remained the same as with PA initially, as there were no sites blocked by AA (no peroxide formation). The results are in line with those obtained using $\mathrm{K}-\mathrm{L}$ equations.

\subsection{I- $V$ characteristics of unit PEM fuel cell}

The performance of the unit PEMFC was evaluated using the synthesized catalyst. Fig. 14(a) and (b) show the peak power densities for samples N1, N2, N3, M1, M2, and M3 as 383, 453, $280,486,818$, and $711 \mathrm{~mW} \mathrm{~cm}^{-2}$, respectively. It is clear that the purified catalyst support raises the kinetics of ORR. These results can be explained by taking an example of a car driven on an uncrowded and smooth road, where fast driving is feasible. On the contrary, heavy traffic will restrict movement of the car. When CNTs have defects, these might act as traps for the oxygen during ORR, thereby leading to slow kinetics. However, when these CNTs are graphitized, surface cleansing and uniformity is
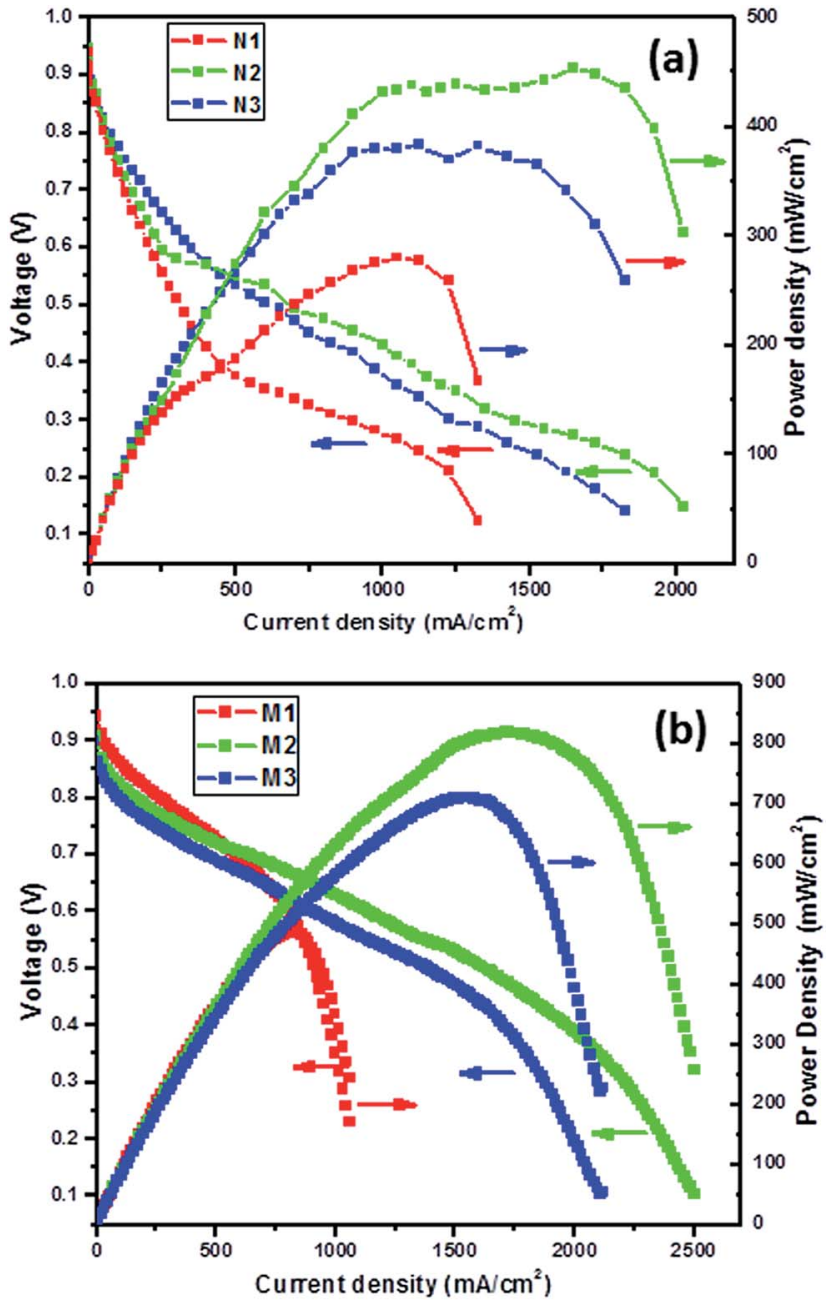

Fig. 14 Comparative current-voltage performance of PEM fuel cell using samples (a) N1, N2, and N3 and (b) M1, M2, and M3 as catalyst. achieved resulting in fast ORR and ultimately higher power density.

It is suggested that interaction between the crystalline Pt NPs and CNTs occurs through synergic bonding that involves redistribution of charge between $2 \mathrm{p}$ orbitals of carbon and $5 \mathrm{~d}$ orbitals of Pt, as depicted in Fig. 15. Such interaction facilitates immobilization of Pt NPs on CNT surface without any functional groups. ${ }^{73}$

The improved performance of the M2 sample can further be attributed to the small size and uniform distribution of the Pt NPs, which results in increase in the overall ECSA and direct reduction of oxygen by a four-electron process.

In the region of low current density of the fuel cell polarization curve, the voltage drop (known as the activation polarization) mainly reflects the sluggish kinetics of the oxygen reduction reaction at the cathode surface. The activation polarization is described by the Tafel equation

$$
\Delta V_{\text {act }}=(R T / \alpha n F) \ln \left(j / j_{0}\right)=a \log j-a \log j_{0}
$$

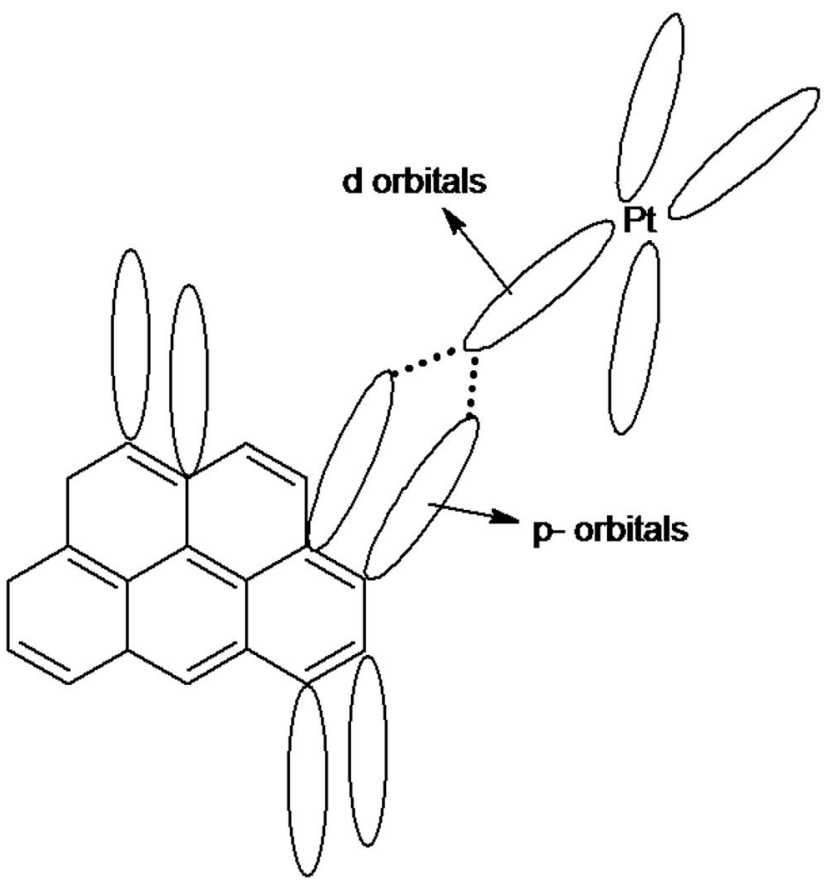

Fig. 15 Schematic of the interaction between labile $2 p$ electrons of carbon and $5 \mathrm{~d}$ electrons of Pt.

Table 2 Electrochemical kinetic parameters for unit PEM fuel cells using catalyst samples N1, N2, N3, M1, M2, and M3

\begin{tabular}{lcccc}
\hline & $E_{0}(\mathrm{~V})$ & $j_{0.9}\left(\mathrm{~mA} \mathrm{~cm}^{-2}\right)$ & $b(\mathrm{~V}$ per decade $)$ & $\alpha$ \\
\hline N1 & 0.939 & 6.52 & $0.1296 \pm 0.0105$ & 0.0991 \\
N2 & 0.949 & 9.20 & $0.0861 \pm 0.0063$ & 0.1491 \\
N3 & 0.915 & 7.59 & $0.1167 \pm 0.0089$ & 0.1101 \\
M1 & 0.918 & 23.77 & $0.0408 \pm 0.0017$ & 0.3149 \\
M2 & 0.902 & 19.01 & $0.0377 \pm 0.0016$ & 0.3408 \\
M3 & 0.869 & 12.12 & $0.045 \pm 0.0011$ & 0.2855
\end{tabular}


Eqn (5) is linear of the form $y=a x+b$, where $a(=R T / \alpha n F)$ is the Tafel slope, $j$ is the current density, $j_{0}$ is the exchange current density, $n$ is the number of electrons transferred per mole of reactant, $F$ is Faraday's constant, and $\alpha$, the charge transfer coefficient represents the fraction of the over potential assisting the reaction. The various kinetic parameters are summarized in Table 2, and the Tafel plots are shown in Fig. 16. The value of $j_{0.9}$ represents the current density at the cell potential of $0.9 \mathrm{~V}$, known as kinetic current density, while $\alpha$ is calculated from the slope of the Tafel plots. The reason for presenting $j$ at a particular cell potential $(0.9 \mathrm{~V})$ rather than $j_{0}$, is because even a slight variation in Tafel slope can cause anomalous variation in the values of $j_{0} \cdot{ }^{74}$ The values of charge transfer coefficient $(\alpha)$ and $j_{0.9}$ were found to be higher for Pt/h-CNT nanocomposites, indicating feasibility of the reaction compared with that with Pt/CNT samples. The value of Tafel slope was calculated to be minimum for sample M2, much smaller than that reported elsewhere. ${ }^{38,74-76}$ This may be
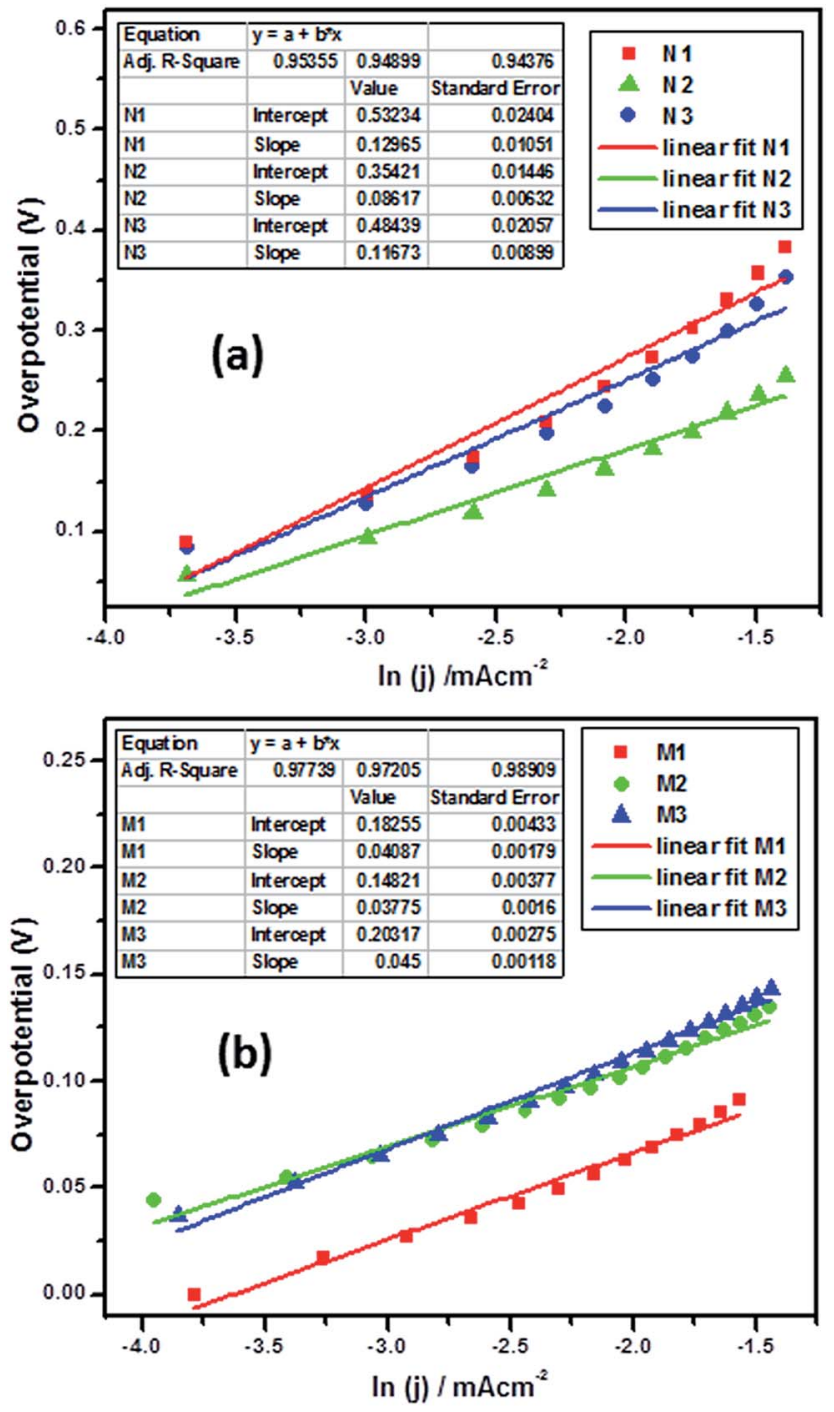

Fig. 16 Tafel plots of the electrochemical reactions with the different catalyst samples. The Tafel slopes were obtained by linear fitting.

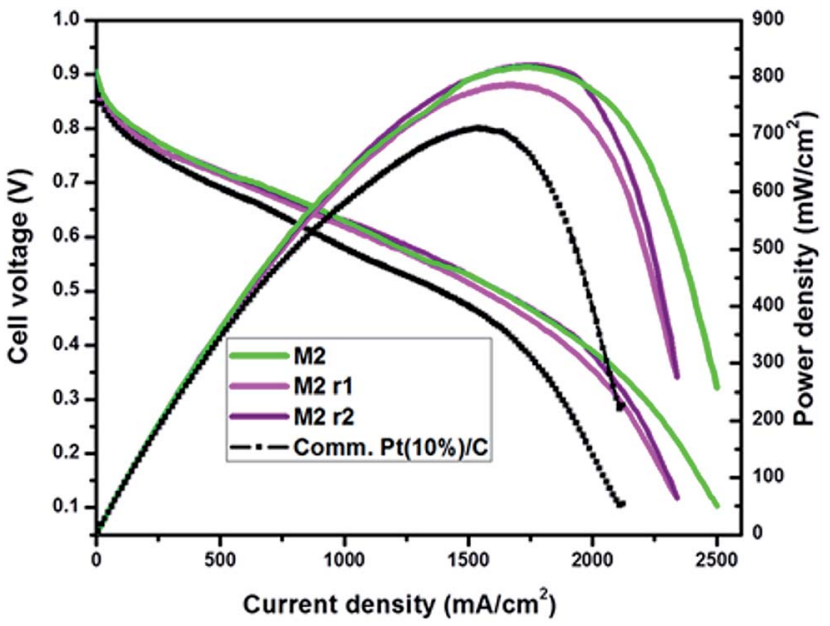

Fig. 17 Current-voltage performance for M2 catalyst repeated two times and compared with JM 40\% Pt/C.

attributed to better Pt utilization, which in turn is accredited to smaller particle size and homogeneous distribution of platinum nanoparticles for sample M2 resulting in an increase in the number of possible reaction sites. Twice-repeated catalyst (10\% $\mathrm{Pt} / \mathrm{h}$-CNTs) synthesis in neutral medium under $\mathrm{N}_{2}$ refluxing (i.e. conditions for sample M2) shows consistent FC performance (Fig. 17). Interestingly, almost a $13.5 \%$ hike in fuel cell performance was achieved while employing sample M2 with $0.25 \mathrm{mg}$ $\mathrm{cm}^{-2}$ Pt loading, compared with a commercial catalyst, i.e. $40 \%$ $\mathrm{Pt} / \mathrm{C}$ (obtained from Johnson Matthey, JM) with $0.5 \mathrm{mg} \mathrm{cm}{ }^{-2} \mathrm{Pt}$ loading and tested under similar conditions.

\section{Conclusion}

Development of a highly efficient electrocatalyst for oxygen reduction reaction (ORR) is key to commercialization of PEM fuel cells. Heat treatment has proved to be a feasible and efficient method for improving the electrochemical activity of CNTs on a large scale, and highly purified MWCNT supported Pt nanoparticles were successfully developed. Pt was reduced in a nitrogen atmosphere, and a neutral medium forms stable complexes that further assist in creating uniformity over available active sites while enhancing the ORR kinetics. The $I-V$ performance of a unit PEM fuel cell for sample M2 showed high peak power density of $818 \mathrm{~mW} \mathrm{~cm}{ }^{-2}$, at Pt loading of $0.25 \mathrm{mg}$. $\mathrm{cm}^{-2}$. The stability of the support (achieved by heat treatment) and the stability of the Pt on it (because of complex ion formation) leads to efficient ORR by a four-electron process.

\section{Acknowledgements}

The authors are grateful to Mr Dinesh Kumar, Mr R. K. Seth, and Mr Naval K. Upadhyaya for carrying out the TEM, TGA, and XRD studies. One of the authors, CG, wants to thank CSIR-SRF, India for financial support. These studies have been carried out under the CSIR project entitled "Development of Advanced Materials for Next Generation Energy Efficient Devices (PSC-0109)". 


\section{References}

1 Y. Wang, K. S. Chen, J. Mishler, S. C. Cho and X. C. Adroher, Appl. Energy, 2011, 88, 981-1007.

2 M. Winter and R. J. Brodd, Chem. Rev., 2004, 104, 4245-4270.

3 C. E. Thomas, Int. J. Hydrogen Energy, 2009, 34, 6005-6020.

4 S. G. Chalk and J. F. Miller, J. Power Sources, 2006, 159, 73-80.

5 B. Rohland, J. Nitsch and H. Wendt, J. Power Sources, 1992, 37, 271-277.

6 T. E. Springer, T. A. Zawodzinski, M. S. Wilson and S. Gottesfeld, J. Electrochem. Soc., 1996, 143, 587-599.

7 O. T. Holton and J. W. Stevenson, Platinum Met. Rev., 2013, 57, 259-271.

$8 \mathrm{~J}$. Zhang, J. Wu and $\mathrm{H}$. Zhang, PEM fuel cell testing and diagnosis, Newnes, 2013.

9 J. Zhang, PEM fuel cell electrocatalysts and catalyst layers: fundamentals and applications, Springer Science \& Business Media, 2008.

10 M. S. Wilson and S. Gottesfeld, J. Appl. Electrochem., 1992, 22, 1-7.

11 L. Li and Y. Xing, J. Power Sources, 2008, 178, 75-79.

$12 \mathrm{H}$. Wang, H. Li and X.-Z. Yuan, PEM fuel cell failure mode analysis, CRC Press, 2012.

13 W. Li, C. Liang, W. Zhou, J. Qiu, Z. Zhou, G. Sun and Q. Xin, J. Phys. Chem. B, 2003, 107, 6292-6299.

14 Z. Liu, L. M. Gan, L. Hong, W. Chen and J. Y. Lee, J. Power Sources, 2005, 139, 73-78.

15 B. Fang, N. K. Chaudhari, M.-S. Kim, J. H. Kim and J.-S. Yu, J. Am. Chem. Soc., 2009, 131, 15330-15338.

16 Z. Liu, L. Hong and S. W. Tay, Mater. Chem. Phys., 2007, 105, 222-228.

17 N. Jung, S. M. Kim, D. H. Kang, D. Y. Chung, Y. S. Kang, Y.-H. Chung, Y. W. Choi, C. Pang, K.-Y. Suh and Y.-E. Sung, Chem. Mater., 2013, 25, 1526-1532.

18 A. Kriston, T. Xie and B. N. Popov, Electrochim. Acta, 2014, 121, 116-127.

19 V. Celorrio, J. Florez-Montano, R. Moliner, E. Pastor and M. J. Lazaro, Int. J. Hydrogen Energy, 2014, 39, 5371-5377.

20 P. Zhang, S.-Y. Huang and B. N. Popov, J. Electrochem. Soc., 2010, 157, B1163-B1172.

21 W. Zhang, J. Chen, G. F. Swiegers, Z.-F. Ma and G. G. Wallace, Nanoscale, 2010, 2, 282-286.

22 G. Sevjidsuren, S. Zils, S. Kaserer, A. Wolz, F. Ettingshausen, D. Dixon, A. Schoekel, C. Roth, P. Altantsog and D. Sangaa, $J$. Nanomater., 2010, 2010, 73.

23 B. Kuppan and P. Selvam, Prog. Nat. Sci., 2012, 22, 616-623. 24 C. Liu, M. Chen, C. Du, J. Zhang, G. Yin, P. Shi and Y. Sun, Int. J. Electrochem. Sci., 2012, 7, 10592-10606.

25 F. A. Viva, M. M. Bruno, E. A. Franceschini, Y. R. J. Thomas, G. Ramos Sanchez, O. Solorza-Feria and H. R. Corti, Int. J. Hydrogen Energy, 2014, 39, 8821-8826.

26 K. Lee, J. Zhang, H. Wang and D. P. Wilkinson, J. Appl. Electrochem., 2006, 36, 507-522.

27 S. M. Andersen, M. Borghei, P. Lund, Y.-R. Elina, A. Pasanen, E. Kauppinen, V. Ruiz, P. Kauranen and E. M. Skou, Solid State Ionics, 2013, 231, 94-101.
28 V. Hacker, E. Wallnöfer, W. Baumgartner, T. Schaffer, J. O. Besenhard, H. Schröttner and M. Schmied, Electrochem. Commun., 2005, 7, 377-382.

29 Z. Liu, X. Lin, J. Y. Lee, W. Zhang, M. Han and L. M. Gan, Langmuir, 2002, 18, 4054-4060.

30 W. Li, C. Liang, J. Qiu, W. Zhou, H. Han, Z. Wei, G. Sun and Q. Xin, Carbon, 2002, 40, 791-794.

31 C.-T. Hsieh, W.-M. Hung and W.-Y. Chen, Int. J. Hydrogen Energy, 2010, 35, 8425-8432.

32 W. Li, C. Liang, W. Zhou, J. Qiu, H. Li, G. Sun and Q. Xin, Carbon, 2004, 42, 436-439.

33 N. Rajalakshmi, H. Ryu, M. M. Shaijumon and S. Ramaprabhu, J. Power Sources, 2005, 140, 250-257.

34 P. Divya and S. Ramaprabhu, J. Mater. Chem. A, 2014, 2, 4912-4918.

35 W. Li, X. Wang, Z. Chen, M. Waje and Y. Yan, Langmuir, 2005, 21, 9386-9389.

36 E. Antolini, Appl. Catal., B, 2009, 88, 1-24.

37 W. Zhang, P. Sherrell, A. I. Minett, J. M. Razal and J. Chen, Energy Environ. Sci., 2010, 3, 1286-1293.

38 C. Gupta, P. Maheshwari, S. Sasikala and R. B. Mathur, Materials for Renewable and Sustainable Energy, 2014, 3, 1-11.

39 H.-W. Ha, I. Y. Kim, S.-J. Hwang and R. S. Ruoff, Electrochem. Solid-State Lett., 2011, 14, B70-B73.

40 B. Seger and P. V. Kamat, J. Phys. Chem. C, 2009, 113, 79907995.

41 A. Ghosh, S. Basu and A. Verma, Fuel Cells, 2013, 13, 355363.

42 E. Antolini, Appl. Catal., B, 2012, 123, 52-68.

43 Y. Xin, J.-g. Liu, Y. Zhou, W. Liu, J. Gao, Y. Xie, Y. Yin and Z. Zou, J. Power Sources, 2011, 196, 1012-1018.

44 B. Fang, J. H. Kim, M. Kim, M. Kim and J.-S. Yu, Phys. Chem. Chem. Phys., 2009, 11, 1380-1387.

45 B. Fang, J. H. Kim, M. Kim and J.-S. Yu, Chem. Mater., 2009, 21, 789-796.

46 W. Zhang, J. Chen, A. I. Minett, G. F. Swiegers, C. O. Too and G. G. Wallace, Chem. Commun., 2010, 46, 4824-4826.

47 A. Jorio, G. Dresselhaus and M. S. Dresselhaus, Carbon nanotubes: advanced topics in the synthesis, structure, properties and applications, Springer Science \& Business Media, 2007.

48 Y. Shao, J. Liu, Y. Wang and Y. Lin, J. Mater. Chem., 2009, 19, 46-59.

49 Y. Shao, G. Yin, J. Zhang and Y. Gao, Electrochim. Acta, 2006, 51, 5853-5857.

50 P. M. Ajayan, Chem. Rev., 1999, 99, 1787-1800.

51 V. N. Popov, Mater. Sci. Eng., R, 2004, 43, 61-102.

52 M.-F. Yu, O. Lourie, M. J. Dyer, K. Moloni, T. F. Kelly and R. S. Ruoff, Science, 2000, 287, 637-640.

53 R. S. Ruoff, J. Tersoff, D. C. Lorents, S. Subramoney and B. Chan, Nature, 1993, 364, 514-516.

54 I. Palaci, S. Fedrigo, H. Brune, C. Klinke, M. Chen and E. Riedo, Phys. Rev. Lett., 2005, 94, 175502.

55 M.-F. Yu, T. Kowalewski and R. S. Ruoff, Phys. Rev. Lett., 2000, 85, 1456-1459.

56 M. Minary-Jolandan and M.-F. Yu, J. Appl. Phys., 2008, 103, 073516. 
57 P. Chaiwan and J. Pumchusak, Electrochim. Acta, 2015, 158, 1-6.

58 P. H. Maheshwari, C. Gupta, V. Selvaganesh and R. B. Mathur, J. Electrochem. Soc., 2014, 161, F1146-F1153.

59 P. H. Maheshwari and R. B. Mathur, RSC Adv., 2014, 4, 22324-22333.

60 C. Lu and J. Liu, J. Phys. Chem. B, 2006, 110, 20254-20257.

61 A. S. Basaev, Semiconductors, 2012, 46, 1613-1615.

62 C. Gupta, P. H. Maheshwari and R. B. Mathur, Adv. Sci. Lett., 2014, 20, 1454-1458.

63 P. H. Maheshwari, R. Singh and R. B. Mathur, Mater. Chem. Phys., 2012, 134, 412-416.

64 B. W. Smith and D. E. Luzzi, in Introduction to Nanoscale Science and Technology, Springer, 2004, pp. 137-182.

65 R. Andrews, D. Jacques, D. Qian and E. C. Dickey, Carbon, 2001, 39, 1681-1687.

66 K. Behler, S. Osswald, H. Ye, S. Dimovski and Y. Gogotsi, J. Nanopart. Res., 2006, 8, 615-625.

67 Y. Wang, J. Wu and F. Wei, Carbon, 2003, 41, 2939-2948.
68 W. Huang, Y. Wang, G. Luo and F. Wei, Carbon, 2003, 41, 2585-2590.

69 Y. Garsany, O. A. Baturina, K. E. Swider-Lyons and S. S. Kocha, Anal. Chem., 2010, 82, 6321-6328.

70 N. Markovic, H. Gasteiger and P. N. Ross, J. Electrochem. Soc., 1997, 144, 1591-1597.

71 U. Paulus, T. Schmidt, H. Gasteiger and R. Behm, J. Electroanal. Chem., 2001, 495, 134-145.

72 D.-H. Lim and J. Wilcox, J. Phys. Chem. C, 2012, 116, 36533660 .

73 J. Zhou, X. Zhou, X. Sun, R. Li, M. Murphy, Z. Ding, X. Sun and T.-K. Sham, Chem. Phys. Lett., 2007, 437, 229-232.

74 G. Selvarani, A. K. Sahu, N. A. Choudhury, P. Sridhar, S. Pitchumani and A. K. Shukla, Electrochim. Acta, 2007, 52, 4871-4877.

75 R. P. O'Hayre, S.-W. Cha, W. Colella and F. B. Prinz, Fuel cell fundamentals, John Wiley \& Sons, New York, 2006.

76 F. Barbir, PEM fuel cells: theory and practice, Academic Press, 2005. 